\title{
Parliament Strikes Back: Agenda-setting and Power Voids in Early Representative Assemblies *
}

\author{
Toni Rodon \\ Universitat Pompeu Fabra \\ toni.rodon@upf.edu
}

\author{
Tom Paskhalis \\ Trinity College Dublin \\ tom.paskhalis@tcd.ie
}

May 31, 2022

\begin{abstract}
Previous research has sought to explain the emergence of early representative assemblies and their eventual primacy over monarchs. Yet, how parliamentarians behaved during the struggles for power remains largely unknown. We contend that parliamentary elites used periods of uncertainty to set the political agenda and show their strive for sovereignty. We test this claim on seventeenth century England by using several sources, including activities reported in the parliamentary journals and lists of elected MPs. In addition, we implement a novel strategy of measuring MPs' agenda-setting power based on entropy of topic shares in daily records of parliamentary activity. Our results show that elites strategically used power voids to expand their attention to a wider set of topics, increase pressure on the monarch and present themselves as rulers which were ready to govern. Our findings have important implications for our understanding of how elites behave in early and contemporary representative assemblies.
\end{abstract}

Keywords: historical institutionalism, representative assemblies, Britain, text analysis

Word Count: 10744

\footnotetext{
*We are grateful to Kenneth Benoit, Jack Blumenau, David Smith, Arthur Spirling, David Stasavage, Daniel Stegmueller, Patrick Kuhn, Lucas Leemann and Kiwi Ting and seminar participants at UCD and UPF for their feedback on earlier drafts. We also thank Julian Hoppit for sharing data on parliamentary acts. This paper also benefited from comments and suggestions received at the EPSA 2020 Annual Meeting, ECPR General Conference 2020, SVPW-ASSP-SPSA Annual Congress 2021 and PSAI Annual Conference 2021.
} 
"This is the crisis of parliaments: we shall know by this if parliaments live or die."

—Sir Benjamin Rudyerd, 1628

\section{Introduction}

The question of how parliaments gained power vis-à-vis the monarch has always been a matter of scholarly interest. Most of the academic debate has revolved around the bargaining process between the Parliament and the monarch, during which parliaments engaged in a struggle with the Crown in order to obtain political concessions in exchange for (mainly) financial support (North and Thomas, 1973; Levi, 1981; North and Weingast, 1989; Boucoyannis, 2015). Despite a large body of literature focusing on the bargaining process between the monarch and early representative assemblies, we still know little about how parliamentary elites behaved during these crucial periods. How did they galvanize political support for their cause? Did they simply ask for political concessions in exchange for financial support? More generally, how did parliamentarians in early representative assemblies push for an institutional change in order to acquire more power?

In this article we study how parliamentary elites behaved during the sixteenth and seventeenth centuries in England's House of Commons and House of Lords. In particular, we focus on the elites' strategies to extract political power from the Crown. Our argument contends that parliamentarians exploited situations of uncertainty, in which a power void occurred, to show they were capable of handling more political attributions-that is, holding more political power. We define a power void as a situation in which power of an identifiable central authority is questioned or the authority is not able to enforce its will. Power voids resulted in uncertainty as to who had control of the situation, and constituted a period characterized by a power struggle and political competition that lasted until a new actor took over.

We argue that parliamentarians used power voids as a window of opportunity to set 
the terms of the debate and strategically display their strive for sovereignty. During these periods parliamentarians increased their efforts to cover a wider range of policy areas in order to make themselves visible to both their electorate and to the monarch. MPs engaged in an agenda-setting strategy to exert more pressure on the monarch. In a context in which elections became more contested and MPs increasingly relied on a limited-but nevertheless important-electorate, elites strove to show they were capable of handling the matters of the realm. Thus, part of the MPs' bargaining strategy, as the conventional explanation has long argued, consisted of demands for political power in exchange for financial support. However, as we show in this article, political elites complemented these demands by increasing their efforts to set the agenda, influence policies and ultimately demonstrate to their constituents and to the monarch they were ready to assume more control on a wider set of issues.

Our article advances previous literature in at least three important ways. First, one of the departing points to explain the rise and preponderance of early parliaments has been the Bargaining Model of Representation (BMR). This model primarily argues that the parliament strove for power in exchange for financial resources (North and Weingast, 1989). However, the BMR still remains highly contentious (Smith, 1999; Stasavage, 2010, 2016; Boucoyannis, 2021). For instance, historians show that, in the English case, the sums of supplied offered by the House of Commons, and mainly due to inflation, "fell so far short of the King's needs that often they were simply not worth bargaining for" (Russell, 1990, 42). In this article we extend the bargaining logic and argue that political elites augmented their negotiation strategy through other means, specifically exploiting power voids by showing their willingness to cover more competences and matters over a wider set of issues. We complement previous works by explaining how parliamentary elites demanded concessions. Thus, MPs resorted to the "redress before supply" logic as a strategic tool, but they also complemented it with an agenda-setting strategy.

Second, we propose a measure of agenda-setting based on the analysis of the House of Commons and the House of Lords parliamentary journals. These journals provide 
overviews of daily parliamentary business and cover the key period in the creation of England's representative institutions. In order to empirically assess the elites' strategy during power voids, we construct a topic entropy-based measure using the Latent Dirichlet Allocation (LDA) model. This indicator allows us to measure the spread of parliamentarians' attention over policy areas and capture how their expressed desire for sovereignty changed over time. Furthermore, our methodological approach provides the first systematic quantitative approach to studying the elites' behavior during the key period of democratic development, which is otherwise difficult to analyze for scholars doing empirical research. Moreover, we investigate alternative explanations and examine several possible mechanisms by exploiting information on MPs, petitions and legislative acts. Overall, our analysis shows neither the composition of MPs, nor changes in topics of petitions are likely explanations for MPs behavior. Instead, MPs were strategic in bringing new topics to the political agenda in order to offer a more effective challenge in their struggle with the monarch.

Overall, this article is based on a polar case study (England during the seventeenth century) and offers a novel way to analyze how parliamentary elites behave in early representative assemblies. Given the influence of the Westminster model, our findings can ultimately offer a way to better understand how and why some countries consolidated a democratic system, while others did not, as well as the elites' behavior in many contemporary legislative assemblies.

\section{Early parliaments, taxation and representation}

Between the twelfth century and 1600, most parts of Europe witnessed the emergence of consultative or representative assemblies that expressed the interests of various segments of the population-typically, the nobility, the army, the Church, and, at a later stage, the cities. Although early assemblies varied in the types of prerogatives they enjoyed and in the social classes they represented, they constitute one of the main institutional innova- 
tions of the middle ages with far-reaching implications for state development and state capacity (North and Thomas, 1973; Boix, 2015; Stasavage, 2020). Parliamentary institutions are considered a crucial feature that limited state expropriation, protected property rights and ultimately became the foundation of the rule of law (North and Weingast, 1989; North, 1990). The presence and activity of parliament, and its constraints on the often abusive power of the monarch, set the conditions to enable modern economic development in Europe (De Long and Shleifer, 1993; Acemoglu, 2005; Acemoglu et al., 2005; Van Zanden et al., 2012; Puga and Trefler, 2014; Cox, 2017) , increased the state's capacity (Dincecco, 2015), such as the ability to finance wars (Tilly, 1975; Harriss, 1976), played an important role in nation-building processes (Smith, 1999) and eventually shaped the institutional design of colonial territories (Hariri, 2012). Last but not least, Boucoyannis (2021) argues that representative institutions emerged when rulers could exercise the power to deliver justice across social groups.

Early representative assemblies usually had four important functions. First, they served as the means by which the monarch could communicate with political elites and gather information. In addition to having a consultative role, these early assemblies also provided a mechanism of political control, as it allowed the monarchy to strengthen political allegiances and to mitigate dissent. Second, medieval parliaments often levied taxes, initially with the consent of the king, and later according to their own will. Third, they had judicial functions. Finally, early parliaments gradually obtained legislative functions. Some early assemblies were able to force the monarch to accept the assent-or the initiative-of Parliament before the king could sanction legislative proposals into law. In general, early representative assemblies, if they did not disappear (Van Zanden et al., 2012), began to acquire certain powers and ultimately became clearly distinguishable from the older (and often informal) king's consultative meetings.

\footnotetext{
${ }^{1}$ The debate is, however, far from settled. For instance, a recent article by Abramson and Boix (2019) shows that parliamentary constraints during the medieval period were themselves outcomes determined by an endogenous process of urban agglomeration and economic growth. Also Stasavage (2010) shows that geography crucially constrained the success of early representative assemblies. Similarly, another strand of literature focuses on the long-term role of culture (Ruck et al., 2020), which, this literature argues, had a more important impact than institutions.
} 
How did early parliaments were able to obtain concessions from the Crown? According to the seminal Bargaining Model of Representation (BMR), the development of parliamentary power was primarily driven by the monarch's need to raise money through taxes. When the income from Crown possessions was no longer sufficient on its own to fund the king's expenditure, the Crown had no option but to convene a representative assembly and sought elite's approval for more resources, which most of the times inevitably meant more taxes.

Following the BMR logic, these demands gave political elites the chance of extracting concessions from the monarch. When resources were lacking, the Crown was forced to bargain. In turn, the elites demanded rights and political and economic powers. This interaction created what is oftentimes known as the 'principle of redress of grievances': the parliament-the political elites that represented the 'commons'-agreed not to grant taxes before the king met its demands. When monarchs were subjected to exogenous (e.g. wars against foreign powers) or endogenous (e.g. bad economic decisions) shocks, the Crown had no option but to enter into negotiations with the parliament. This bargaining process between the political elites and the ruler unleashed a process that often led to institutional change (Greif and Laitin, 2004) ${ }^{2}$.

However, this conventional wisdom in political science literature still has some important gaps to address. First, historians have collected data on the specific reasons for summoning early representative assemblies that often gives us a different picture than that depicted by the BMR. Møller (2017) shows that for the Crown of Aragon between 1100-1327 the most important reason was to establish public order through land peace and regulation of succession. It is true that, as shown by Møller (2017), the pattern was different in England, where taxation and warfare were by far the dominant reasons for convoking assemblies in this period. However, one can find many instances in which the English Parliament mainly clashed over different policy priorities and not as a result of a

\footnotetext{
${ }^{2}$ The difference in monarch's negotiation capacity across different European countries might also explain why some monarchs granted concessions before others-if they granted them at all. For instance, according to Levi $(1989,97)$, "the relatively weaker bargaining position of English monarchs vis-à-vis their constituents led to concessions that French monarchs did not have to make".
} 
direct demand of political power from the parliamentarians to a king in need for financial support.

Second, the bargaining logic necessarily implies that the Crown was forced to negotiate over scarce resources and was very often willing to transfer part of its powers to the Parliament. As previous works have shown, this logic fits better at later stages, when the parliament already possessed some power. Yet, it fits worse in understanding when representative institutions or rights emerged or consolidated (Levi, 1989; Boucoyannis, 2015). Besides financing war, much of the conflict between the Crown and the Parliament in sixteenth and seventeenth century England revolved around the distribution of the spoils of office (Gruenfelder, 1981). Monopolization of patronage by the Crown-for instance, through state monopolies-helped to enlarge the division between the court and the parliamentary elites. Most crucially, Boucoyannis (2021) has recently shown that the English parliament emerged because the monarchy was strong, and not weak, and was able to compel the different elites and solve their collective action problem.

Third, the BMR posits that taxation demands by rulers were accompanied by elite demands for representation. Conflicts thus set in motion a bargaining process in which grievances among the political elites were redressed and, subsequently, more resources to the Crown were granted. However, the redress of grievances might not have been as common as the model would predict. The demand for representation or concessions did not always lead to an agreement, but to a conflict or even outright war. The American case is paradigmatic: when the British demanded taxes and the Americans demanded self-government, the outcome was a revolutionary war. In England, on many occasions MPs voted in favor of granting higher resources to the monarch without obtaining concessions. In other cases the monarch simply dissolved the Parliament before granting them (Boucoyannis, 2015). Overall, historians detail that MPs preferences often went beyond a simple demand of concessions and that fundamental disagreements over policies were also at the core of the conflict (Hill, 1980; Smith, 1999).

Finally, previous work generally focused on the two extremes of the bargaining process: 
the start of the negotiation process (e.g. war) and the outcome. However, we still have little knowledge of what happened in between, namely, on the elite's behavior during these periods of negotiation. How did representatives exploit the political opportunities? Or, more broadly, what did elites do during power voids?

\section{$3 \quad$ Exploiting power voids}

Our argument contends that elites in early representative assemblies exploited power voids to manifest their claim for sovereignty over the realm. These periods created opportunity windows for elites to position themselves for extracting political concessions. In order to show they were able to assume more power, parliamentary elites combined direct demands to the monarch with a political strategy that consisted of positioning themselves as able to govern in many political domains. In other words, during these power voids, parliamentarians strove to set the political agenda by covering a wider range of policy areas, even if they did not have 'real' formal power. They presented themselves as "ready" to assume more sovereignty. We know from contemporary research that politicians often use their position to attempt to influence the public by establishing a hierarchy of topics prevalence (Lippmann, 1922; McCombs and Shaw, 1972; Rogers and Dearing, 1988). We argue that political elites followed a similar strategy in order to heighten their challenge to the monarch, as well as present themselves as ready to govern.

Thus, we argue that alongside power demands political elites engaged in an agendasetting process during these power struggles in which they tried to highlight issues to their political advantage and set the terms of the political debate. Our contention is that elites were strategic agents that exploited power voids in order to gain leverage over the monarch and to strengthen their position.

In line with the BMR model, we conceive this as a multi-stage process. At first, the Crown possesses most power-'the power of the purse'-and does not need to rely on the parliament, which mainly serves as an advisory committee, has limited power, and is 
summoned according to the monarch's will. Even the parliament's continued existence is at the monarch's discretion, since it is subject to dissolution at any time.

At a second stage, a power void occurs and sets in motion a political struggle, principally, over the sovereignty of the realm. On the one hand, the Crown's preference is to keep all the power, extract financial resources, and, if possible, to roll back power concessions to the parliament that were granted in the past. On the other, the parliament wants to keep its powers and extract more concessions from the monarch over certain matters. These stages constitute the core of the traditional bargaining model.

The third stage occurs during a critical process-a power void-and focuses on the way actors express their preferences. During the "redress of grievances" negotiation stage, political elites engage in a process of widening their interest to a broader set of sovereignty issues. In other words, parliamentary elites strive to make themselves visible by highlighting a diverse and broader set of topics. By broadening their claims, parliamentary elites offer a more encompassing challenge to the monarch, who now has to face not only tax-related claims, but also actors that highlight many other policy issues and portray themselves as ready to accept power over them. Thus, political elites aim at setting the terms of the debate through an agenda-setting exercise that gives them further leverage to negotiate with the monarch.

Finally, on the fourth and last stage a new equilibrium emerges, either as a result of an agreement or when one of the sides is "defeated".

Our argument therefore implies that elites used periods of uncertainty to focus their attention on a wider variety of topics. This is consistent with historical accounts that show that constitutional bargaining in England took place in numerous dimensions of policy not only restricted to taxation (Herb, 2003; Tilly, 1975). In addition, previous research has also shown that transitions from monarchy to parliamentary dominance occurred during unsettled periods or when rulers were weak (Stasavage, 2016). The new equilibrium is once again partly based, we argue, on the strategic behavior of parliamentary elites, who sought to outmaneuver the monarch and convince the constituents of their capacity to 
take over new policy areas.

It is important to note that this agenda-setting exercise was not exclusively pursued to obtain more formal power. During power vacuums MPs also engaged in an agendasetting process with an eye kept at their constituents-as it happened a few decades later, on the beginning of the XIX century (Aidt and Franck, 2019). During the seventeenth century, some elections became increasingly contested and MPs position on the Parliament often circulated in newsletters or copies of parliamentary speeches (see Appendix B). MPs usually argued with the Crown's government over how a policy was implemented. For instance, in 1621 the Commons tried to make its vote of taxation conditional on a declaration of war on Spain-James decided a year later to dissolve Parliament without obtaining supplies. In 1626 the Parliament showed strong opposition to the granting of liberty of worship to Catholics in England. As argued by Hill (1980, 61), the Commons tried to steal the initiative from Privy Councillors, not always "from any conscious desire to usurp state power, but because MPs wanted different policies to be pursued". Perhaps the best example comes from the Grand Remonstrance, a list of grievances presented to King Charles I in 1641 that included 204 separate points of objection, covering matters such as foreign, financial, legal and religious policies. While the Grand Remonstrance was being negotiated, the Commons actively appealed to public opinion by publishing and circulating the draft of the document in order to force the King's hand (Zaret, 1996; Raymond, 1998).

Overall, parliamentary elites pursued a dual strategy. On the one hand, they bargained with the monarch to formally "redress the grievances before supply", as the standard bargaining model predicts. On the other, when the opportunity presented itself, they also engaged in an agenda-setting strategy, demonstrating their claim over a wider set of policy issues. 


\section{The English Parliament}

Compared to other early assemblies across medieval Europe, the Parliament of England was unusual in three important aspects. First, it combined the roles of a representative assembly and a court of law. Second, it allowed its members to present petitions in order to seek authoritative judicial resolution of grievances by the King and his extended Council. Third, the English Parliament had a bicameral structure-the House of Commons and the House of Lords (North and Thomas, 1973; Smith, 1999).

In the beginning co-operation, rather than conflict, was the normal relationship between the parliament and the monarchy (Hill, 1980; Smith, 1999). This is illustrated with the number of parliaments called by monarchs in the middle ages-nearly 200 between 1272 and 1399 and over 50 up until 1485.

The incessant warfare between England and Scotland, and then France, in the fourteenth century cemented the place of the Commons in parliament, as the Crown regularly looked to MPs to provide the funds necessary for defense and military campaigning. The social classes represented by the Parliament, especially in the Commons, were getting richer, while the government was getting relatively poorer. Government expenditure was rising rapidly and hence it grew more dependent on the taxes the Parliament voted, even in times of peace. The Commons was always sensitive to the idea that the King had a right to levy arbitrary taxation: parliamentarians did not want the King to become financially independent of the taxes they voted (Hill, 1980; Smith, 1999).

As mentioned above, when we look at the evolution of the Commons, the bargaining dynamic is still controversial, especially among historians. For instance, Cogswell (1990, 283) explains that "much the parliament men might have liked redress to have preceded supply, [but] they were arguably far too weak to see that the king corrected the grievances of their constituents before they approved any new taxation”. Or Sharpe (1986, 321) maintains that "the House of Commons in early Stuart England never successfully used, and seldom, attempted to use, the 'weapon' of withholding supply in order to secure redress 
of grievance" (Russell, 1976; Cogswell, 1990). More recently, Boucoyannis (2021) argues that MPs acquired power after the monarch was able to compel them into parliament and not as a result of a monarch's weakness.

Parliaments of 1620s are often considered exemplary cases of political elites exerting pressure that went beyond the logic of redress of grievances before supply (Smith, 1999; Thrush and Ferris, 2010). Thanks to the continental crisis, the Commons were in session for almost $20 \%$ of time between 1621 and 1628. The extraordinary number of sessions provides an excellent sample from which to assess parliament's vis-à-vis the monarch. In line with the bargaining logic, the zenith of parliamentary power and influence should coincide with periods of warfare in which cash-poor monarchs were eager for parliamentary support and subsidies. Therefore, if early Stuart parliaments could not extract redress during war years, one might argue that it is unlikely that they ever could.

Historians repeatedly point to the fact that MPs embraced other strategies, most frequently they strove to set the terms of the policies that could potentially benefit them. As Cogswell (1990) shows, the regular sessions (especially in war time) improved the self-esteem of the Commons and helped them find common ground, for instance against the Crown's monopolies, which substantially hurt their businesses, or in favor of the right of deciding election disputes-and the spoils associated with them. Longer sessions gave MPs' experience and the habit of working together, which eroded the idea that the monarch was the 'natural ruler' to shape policies at his will (Hill, 1980). Boucoyannis (2021) shows that parliamentarians very often seek to resolve judicial disputes over land or other properties. The 'power of the purse' presumed extracting political power from the monarch, but it also often presumed controlling the political agenda.

\section{Data}

To test our argument we need to obtain the data on parliamentary activity in the sixteenth and seventeenth century. Critically, Hansard archive, the comprehensive collection of 
parliamentary debates, frequently used by scholars (Eggers and Spirling, 2014, 2018) historically only appeared in the nineteenth century which leaves us with no records of the minutiae of debates. However, textual records for this period are present in the form of parliamentary journals, overviews of daily parliamentary business, which are available for as early as 1547 for the House of Commons ${ }^{3}$. These texts, originally published in $1802^{4}$ have been recently digitized by British History Online ${ }^{5}$ using a double re-keying method. Instead of using optical-character recognition (OCR), followed by manual checks, with double re-keying texts are manually transcribed from page scans by two independent typists $^{6}$. Any discrepancies arising during this process are then manually resolved. This process ensures high data integrity and fewer errors compared to automated techniques. We wrote a scraper to download systematically all volumes of parliamentary journals for both Houses. Journals are organized in 12 volumes with daily parliamentary sittings as individual records within those. We treat these texts generated on a daily basis as individual observations. Overall, we obtained 8,650 texts for the House of Commons and 8,574 for the House of Lords.

It is worth noting that parliamentary journals were designed to help clerks keep abreast of parliamentary business and differ from Hansard data in several important respects. They contain few mentions of actual debates and virtually no verbatim quotes of delivered speeches ${ }^{7}$. Rather, the focus is on providing a record of decisions made, orders and letters issued and bills passed. In this sense, they are more akin to meetings' minutes than transcripts. As our interest lies in understanding the bargaining process between the Crown and the Parliament, rather than within-parliamentary dynamic, the absence

\footnotetext{
${ }^{3}$ The House of Lords was the first to adopt the Journal as a tool for keeping track of parliamentary business.

${ }^{4}$ Original publication of the Journals of the two Houses was based on the earlier manuscripts. The ones for the House of Commons, however, were destroyed in the fire of the Palace of Westminster in 1834 (Bond, 1971). While the editors introduced a number of changes, predominantly in the formatting and text lay-out, crucially, for the purposes of this study there is no indication that the actual content was modified. See Smith (1999) for further details on historical sources about seventeenth century parliament.

${ }^{5}$ https://www.british-history.ac.uk/

${ }^{6}$ See Appendix A for an example.

${ }^{7}$ In fact, starting from 1624 the clerks were urged to avoid a formal record of debates in order to deny the possibility for the Crown to use those records against individual members.
} 
of information about individual speeches and parliamentarians does not pose a grave problem for the ensuing analysis. Furthermore, the analysis of parliamentary journals as opposed to any other written source from this period, such as diaries of parliamentarians, has several advantages. First, despite some changes over time in the earlier years of their existence journals' composition remained remarkably stable over time, with uniform conventions guiding the work of clerks who compiled them. In addition to customary continuity, the lengthy tenures of the clerks of the parliament ensured the consistency of personal styles over multiple years. For example, John Browne served as the Clerk of the Parliament from 1660 to 1691 (Bond, 1971), a critical period for our analysis. ${ }^{8}$ And there were just 9 clerks throughout the seventeenth century. Second, parliamentary journals preserve relative impartiality, especially when compared to personal records of individual legislators. And, third, relative to other available sources for this period digitized journals provide an unparalleled data quality.

Figure 1 shows the general trends in the data. Until around the turn of the century both the number of texts recorded as well as their length remain very low. The most prominent feature of the plots across both Houses is a visible spike during the period of the English Civil War and the sitting of the Long Parliament. Also, notably, parliamentary sessions become longer and more frequent in the aftermath of the Civil War. As the primary focus of this paper is the power struggle between the monarch and the Parliament, in what follows we restrict out attention to the parliamentary sessions and activity recorded in the Journals during the seventeenth century ${ }^{9}$. Table 1 shows further details on the English Parliaments that sat in this period. Imposing this temporal constraint leaves us with 8,007 daily reports for the House of Commons and 5,230 for the House of Lords. While we constrain our empirical analysis for theoretical reasons, the availability of data prior to 1600 s also limits potential analysis for earlier periods.

\footnotetext{
${ }^{8}$ There is no indication that John Browne, or any other clerk was supportive of the royalist or republican cause-or any other political cause. Clerks had to follow a policy of political neutrality.

${ }^{9}$ See, however, Appendix $\mathrm{G}$ for some results for the late Tudor period.
} 
Figure 1: Overview of Parliamentary Journals for the House of Commons and the House of Lords.
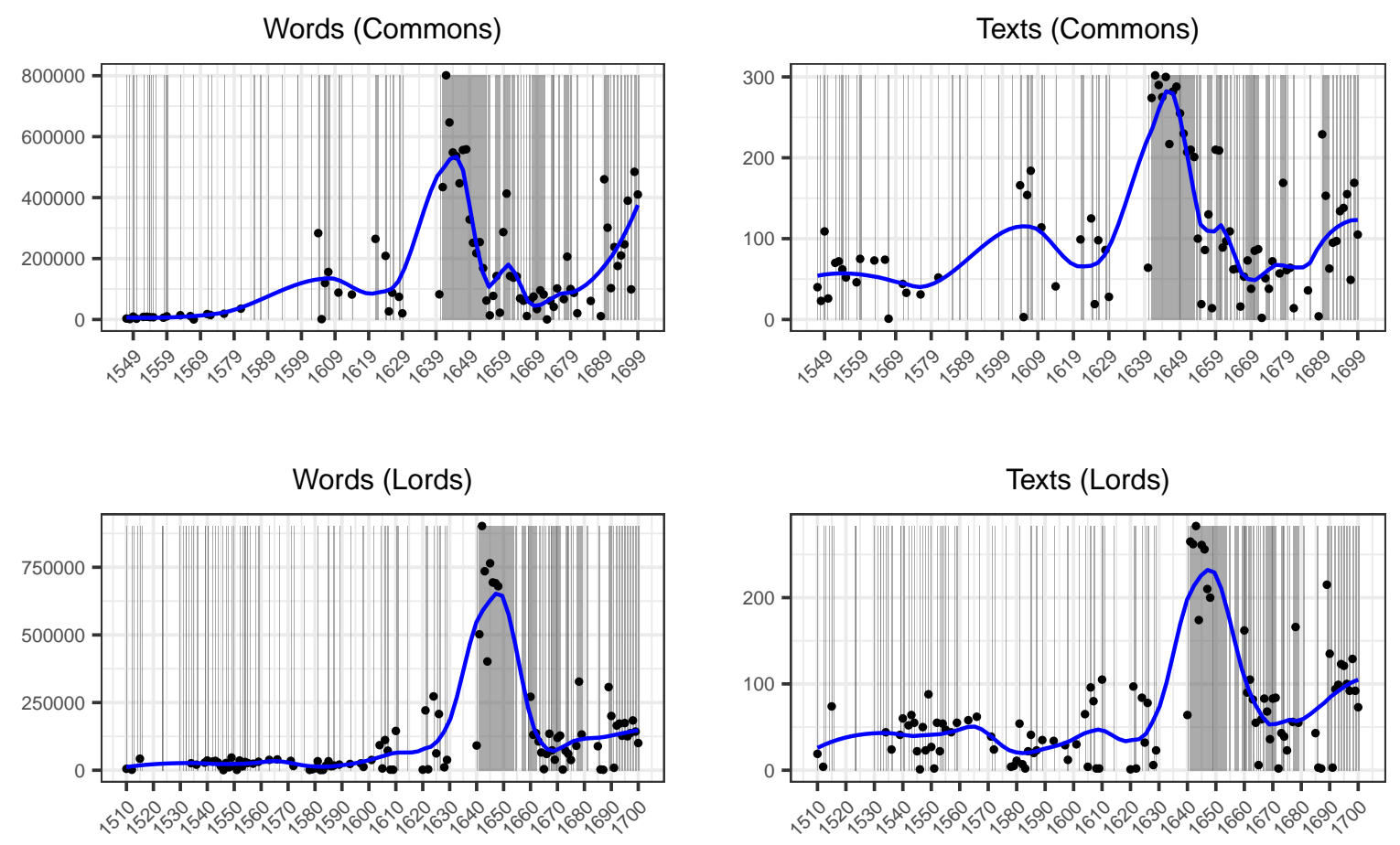

Note: Grey areas show when the Parliament was in session. Dates of parliamentary sessions are based on Fryde et al. (1986). 
Table 1: Summary of Seventeenth Century Parliaments in England.

\begin{tabular}{|c|c|c|c|c|c|c|c|c|}
\hline Parliament & Name & Crown & Sessions & Days in sessions & Assembled & Dissolved & Texts in Commons & Texts in Lords \\
\hline 1601 & 10th Parliament of Elizabeth I & Elizabeth I & 1 & 53 & 27 October 1601 & 19 December 1601 & 0 & 30 \\
\hline $1604-1610$ & Blessed Parliament & James I & 5 & 756 & 19 March 1604 & 9 February 1611 & 621 & 354 \\
\hline 1614 & Addled Parliament & James I & 1 & 63 & 5 April 1614 & 7 June 1614 & 41 & 0 \\
\hline 1621 & 3rd Parliament of James I & James I & 1 & 322 & 16 January 1621 & 6 January 1622 & 99 & 97 \\
\hline 1624 & Happy Parliament & James I & 1 & 100 & 12 February 1624 & 27 March 1625 & 125 & 84 \\
\hline 1625 & Useless Parliament & Charles I & 1 & 55 & 17 May 1625 & 12 August 1625 & 19 & 32 \\
\hline 1626 & 2nd Parliament of Charles I & Charles I & 1 & 129 & 6 February 1626 & 15 June 1626 & 98 & 78 \\
\hline 1628-1629 & 3rd Parliament of Charles I & Charles I & 2 & 150 & 17 March 1628 & 10 March 1629 & 114 & 29 \\
\hline 1640 & Short Parliament & Charles I & 1 & 22 & 13 April 1640 & 5 May 1640 & 19 & 18 \\
\hline $1640-1653$ & Long Parliament & Charles I & 1 & 2954 & 3 November 1640 & 20 April 1653 & 3238 & 1957 \\
\hline $1640-1653$ & Rump Parliament & Interregnum & 1 & 1596 & 3 November 1640 & 20 April 1653 & 3238 & 1957 \\
\hline 1653 & Barebone's Parliament & Interregnum & 1 & 161 & 4 July 1653 & 12 December 1653 & 138 & 0 \\
\hline $1654-1655$ & 1st Protectorate Parliament & Interregnum & 1 & 233 & 3 June 1654 & 22 January 1655 & 119 & 0 \\
\hline $1656-1658$ & 2nd Protectorate Parliament & Interregnum & 1 & 505 & 17 September 1656 & 4 February 1658 & 230 & 0 \\
\hline 1659 & 3rd Protectorate Parliament & Interregnum & 1 & 85 & 27 January 1659 & 22 April 1659 & 70 & 0 \\
\hline $1659-1660$ & Rump Parliament & Interregnum & 2 & 215 & 7 May 1659 & 13 October 1659 & 134 & 0 \\
\hline $1659-1660$ & Long Parliament & Interregnum & 1 & 24 & 21 February 1660 & 16 March 1660 & 3 & 0 \\
\hline 1660 & Convention Parliament & Charles II & 1 & 248 & 25 April 1660 & 29 December 1660 & 164 & 162 \\
\hline 1661-1671 & Cavalier Parliament & Charles II & 18 & 3128 & 8 May 1661 & 24 January 1679 & 1161 & 1080 \\
\hline 1679 & Habeas Corpus Parliament & Charles II & 1 & 82 & 6 March 1679 & 12 July 1679 & 60 & 55 \\
\hline $1680-1681$ & Exclusion Bill Parliament & Charles II & 1 & 81 & 21 October 1680 & 18 January 1681 & 65 & 0 \\
\hline 1681 & Oxford Parliament & Charles II & 1 & 7 & 21 March 1681 & 28 March 1681 & 7 & 0 \\
\hline 1685 & Loyal Parliament & James II & 2 & 55 & 19 May 1685 & 2 July 1687 & 36 & 48 \\
\hline $1689-1690$ & Convention Parliament & William III \& Mary II & 2 & 310 & 22 January 1689 & 6 February 1690 & 250 & 236 \\
\hline $1690-1695$ & 2nd Parliament of William \& Mary & William III \& Mary II & 6 & 755 & 20 March 1690 & 11 October 1695 & 628 & 529 \\
\hline 1695-1698 & 3rd Parliament of William \& Mary & William III \& Mary II & 3 & 549 & 22 November 1695 & 7 July 1698 & 388 & 336 \\
\hline $1698-1700$ & 4th Parliament of William \& Mary & William III \& Mary II & 2 & 295 & 24 August 1698 & 19 December 1700 & 121 & 175 \\
\hline
\end{tabular}

Note: Number of texts indicates the count of proceedings recorded in parliamentary journals. 


\section{$6 \quad$ Measuring Agenda-Setting}

Our primary quantity of interest is the agenda-setting dynamics of the English Parliament in the seventeenth century. While the power or influence of individual political actors started to receive increased scholarly attention in recent years (Eggers and Spirling, 2018; Blumenau, 2021), measuring institutional power requires an alternative approach. Building on our theory of agenda-setting during power voids, we anticipate the desire of the Parliament to influence matters over the realm to be manifested in the distribution of attention over policy areas. In order to build up support amongst its constituents, members of representative assemblies would bring up different topics-preferences, grievances...-and defend interests of a more diverse set of constituents. Thus, our measurement strategy should incorporate the composition of policy issues that members focused over time.

We propose to measure institutional power by analyzing the distribution of policy issues from textual records. The most practical way to capture these policy areas from text is to estimate topics with Latent Dirichlet Allocation (LDA) model (Blei et al., 2003). In this model individual documents are treated as collections ('bags') of words generated by one or more topics. Thus, each document can be characterized by a multinomial distribution over topics and each topic can be characterized by a multinomial distribution over words ${ }^{10}$. However, rather than being interested in the specific topics and their evolution, we will focus on the distribution of topic proportions and the temporal shifts in those. More specifically, we propose to use topic entropy as the relative measure of the desire for institutional power. We argue that agenda-setting power is manifested in how much liberty an institution can have in covering a wider range of policy areas. While entropybased measures have been used before in the literature ${ }^{11}$, to the best of our knowledge, we are the first to adapt it for assessing institution-level agenda-setting power.

To illustrate the intuition behind topic entropy as a measure of agenda-setting, let us present an example of a situation in which the entire policy domain consists of 3 dis-

\footnotetext{
${ }^{10}$ For more technical treatment of the underlying statistical model see Appendix C.

${ }^{11}$ The empirical strategy of this paper builds upon the study of the history of ideas using topic models by Hall et al. (2008).
} 
crete areas: military, agriculture and commerce. Parliamentarians can decide to dedicate their attention to one, two or all of these areas. Assuming limited time, they can spend parts of parliamentary session on each of them. For example, consider the split-up of $(0.9,0.05,0.05)$, meaning that MPs spent $90 \%$ of the time on military affairs, $5 \%$ on farming and agriculture and $5 \%$ on issues of commerce ${ }^{12}$. We contend that this policy concentration was a sign of parliamentary weakness, with the Crown essentially setting a singleissue agenda, thus, constraining parliamentarians' responsiveness to their constituents. On the contrary, partitioning the time of parliamentary session into $(0.6,0.2,0.2)$ policy area vector, indicated Parliament's goal to control the agenda build up support for its case $^{13}$.

More formally, let $M$ represent the total number of policy areas with $a_{j} \in\{1, \ldots, M\}$ and $N$ represent the total number of documents, $d_{i} \in\{1, \ldots, N\}$. Each document $d_{i}$ is assumed to be a vector over policy areas $\boldsymbol{d}=\left(p_{a_{i 1}}, \ldots, p_{a_{i M}}\right)$, where $p$ is the proportion of time dedicated to policy area $a_{j}$, such that $\sum_{j=1}^{M} p_{a_{i j}}=1$. We define the empirical distribution of policy areas within document $d_{i}$ as the distribution of topics $\hat{p}_{d_{i}}$ estimated with LDA. The amount of topic variety expressed in a single document can thus be measured as the topic entropy of this document:

$$
H\left(d_{i}\right)=-\sum_{j=1}^{M} \hat{p}_{a_{i j}} \log \hat{p}_{a_{i j}}
$$

In its original formulation, entropy measures the average amount of information for each symbol in a message (Shannon, 1948). Consider, for example, the illustrative case with three policy areas and two vectors $(0.9,0.05,0.05)$ and $(0.6,0.2,0.2)$, discussed above. In the first case the estimated entropy of a document would be 0.39 , while the latter would give 0.95 . In other words, if the topic distribution is more evenly divided between different

\footnotetext{
${ }^{12}$ Indeed with earlier parliaments often summoned in times of war in order to raise taxes for military campaign, this distribution is not unlikely.

${ }^{13}$ We make no assumptions about the distribution of issue attention from the perspective of an individual MP. In other words, it is perfectly plausible that each individual parliamentarian is always solely focused on a single topic. In which case our measure captures not the mixture of policy issues within MP, but the mixture of MPs with varying degrees of attention to different policy areas.
} 
policy areas, the document is considered to reflect a position in which the parliament covers a wider set of topics during a given sitting. And, conversely, it goes down when the document is narrowly focused on a single issue.

Unfortunately, validating estimates obtained for individual documents, that is, the amount of topics expressed during daily parliamentary sitting, is nigh impossible, given the discussed epoch. To alleviate this problem we aggregate the estimates for all reports that covered parliamentary business within a given year ${ }^{14}$. In this way we can rely on some historical data that is available on a yearly basis. Thus, instead of focusing on $H\left(d_{i}\right)$, we calculate the average $\bar{H}\left(d_{(t)}\right)$ for reports documenting parliamentary proceedings in year $t$. An additional methodological advantage of this approach is the availability of uncertainty estimates for agenda-setting scores (Benoit et al., 2009). We can calculate those using standard deviation of document entropies from each year in our corpus.

As is common practice in the literature (Lauderdale and Clark, 2014; Barberá et al., 2019), we fit LDA model using collapsed Gibbs sampler (Griffiths and Steyvers, 2004), a Markov chain Monte Carlo technique for estimating Bayesian models. Relative to variational inference (Blei et al., 2003), this approach permits more flexible model selection through comparison of marginal likelihoods of models with different number of topics. As the correct number of policy areas is impossible to know ex ante, for diagnostic purposes we fit LDA with a different number of topics, ranging between 5 and 100, on the entire corpora for each House. We further restrict each yearly corpus to documents that contain at least 10 words. In addition to the usual candidates for feature trimming such as punctuation, numbers and common stopwords in English, we further remove some Latin words (such as the Latin names of days and months ${ }^{15}$ ) that are subsets of documents for each House and year pair. Our model selection process was guided by the combination of statistical fit and substantive interpretability. The rest of the results here are shown

\footnotetext{
${ }^{14}$ It should be noted that the estimates of topic entropies obtained for the entire year can be sensitive to the size of corpus available within a given year. However, as we show in the additional results available in Appendix H.1, yearly estimates for very early periods of late Tudors, for which there are few record in the Journals also display high average topic entropies.

${ }^{15}$ See Appendix C.2 for the full list of removed stopwords.
} 
using LDA with the number of topics set to 10. However, as we show in Appendix C.4, the main results are robust to alternative analytical choices.

\section{Results}

\subsection{Validation}

Validating estimates of text analysis models remains a crucial step of the research process (Grimmer and Stewart, 2013). This becomes even more important and also considerably more challenging for research that involves distant historical periods. Even for one of the most bureaucratically developed states of its time, the amount of systematically collected (and preserved) information for England of the seventeenth century is rather limited. Perhaps, the measure most useful for our purposes here, amongst the metrics frequently quoted by historians (Hoppit, 1996; Smith, 1999; Hoppit, 2017), is the number of public and private acts passed by the Parliament in each year. While it is unlikely that there is a perfect correlation between the observed number of parliamentary acts and the latent parliamentary desire for power, the association between the two can provide a reasonable test of our measurement model.

Figure 2 shows estimated yearly mean topic entropy for both Houses plotted against the number of parliamentary acts passed in this year. We find moderate and positive correlation between the two measures. For the Commons (Pearson) correlation is 0.52 $(t=4.4, d f=53, p<0.001)$, while for the Lords it equals $0.49(t=3.6, d f=41$, $p<0.001)$. Despite this association there are some notable discrepancies between the two. For instance, the year 1662 has seen one of the highest numbers of passed acts in a single year in the seventeenth century - 112. However, this happened at the height of the Restoration and was the result of declaring null and void all statutes of 1640s and 1650s that were passed unilaterally by the Parliament and did not receive royal assent. In essence, this covered most of legislation passed during the Interregnum. Removing so many legislative acts (almost 1,000 in total) necessitated the passage of additional bills 
Figure 2: Mean Topic Entropy and Yearly Number of Passed Parliamentary Acts.

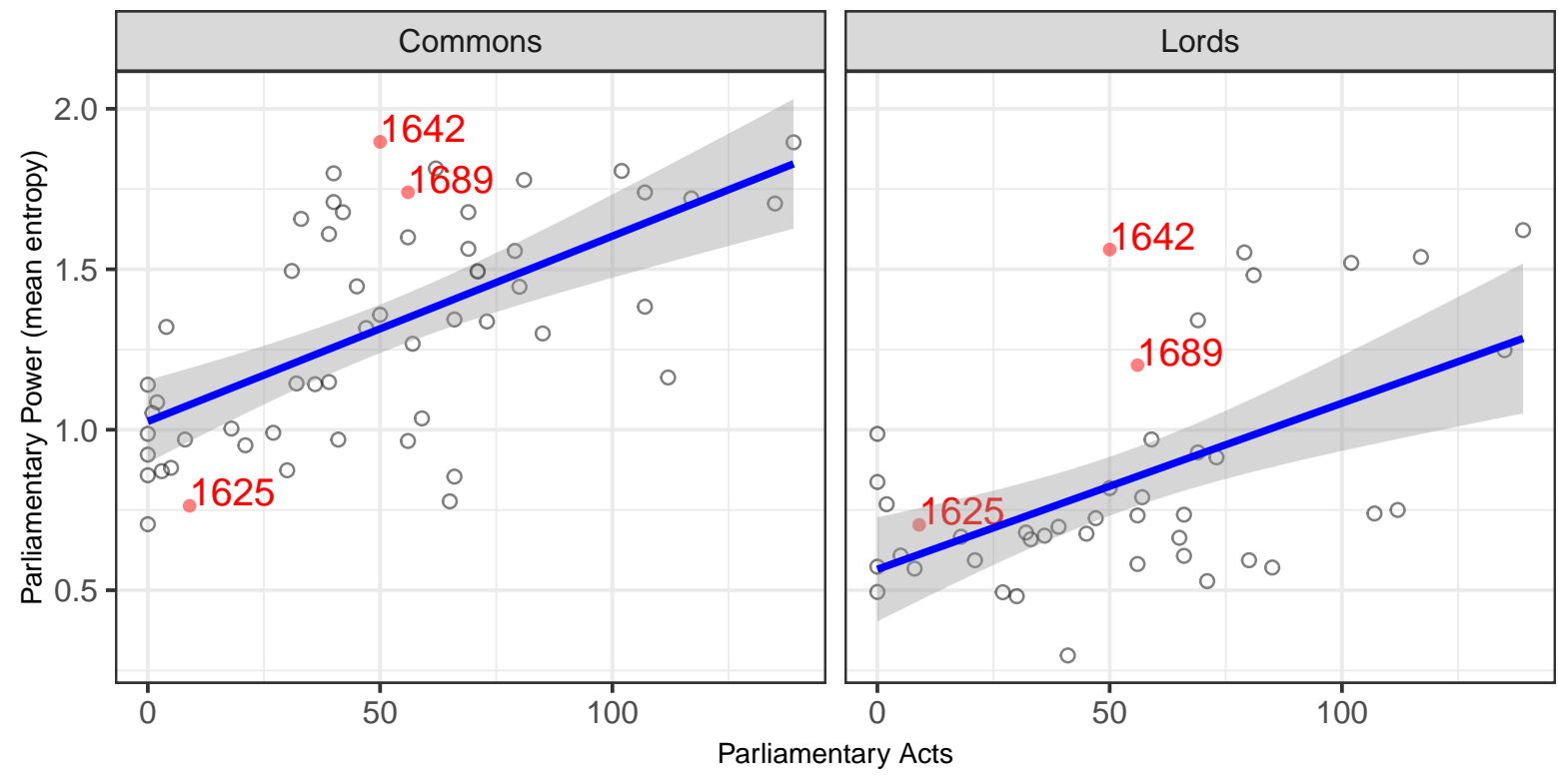

Note: The results of LDA model with 10 topics are shown. The estimates for Useless Parliament (1625), the start of the English Civil War (1642) and the Glorious Revolution (1689) are highlighted. The number of parliamentary acts for 1604-1642 and 1660-1699 is based on Hoppit (1996) and Smith (1999), respectively. For the Interregnum period we collected the list of all parliamentary acts reported in Firth and Rait (1911) and calculated the totals for each year.

and reflected the restoration of the royal authority and the House of Lords rather than any gains of power achieved by the Parliament in that year.

It is worth noting that, on average, across the seventeenth century, we find that parliamentarians in the House of Lords discussed a narrower set of topics than the House of Commons. This is consistent with the subordinate role often attributed to the upper chamber by historians. Direct appointment by the monarch undoubtedly restricted agenda-setting power of the upper House (Smith, 1999). The advantage of our measure in this respect is the possibility to estimate the level of power independently for two Houses. As the passing of bills required the consent of both, it is impossible to observe any between-chamber variation using other measures. There are a few other notable differences between the Commons and the Lords. Most importantly, the number of observations differs between the two Houses as the House of Lords was abolished in 1649 
and did not re-convene until the Restoration in 1660.

\subsection{Temporal Changes}

How do MPs agenda-setting exercise behave over time? Do we find, as posed by our argument, that parliamentary elites aimed at setting the agenda, covering a wider set of topics, during times of political uncertainty? The political history of the seventeenth century England can be broadly segmented into 4 distinct periods: (1) Early Stuart Parliaments (1604-1640), (2) Revolutionary Parliaments (1640-1660), (3) Restoration Parliaments (1660-1689) and (4) Post-Glorious Revolution Parliaments (1689-1699). The first of those periods saw an increased tension between the Crown and the Parliament, which met rather infrequently. In 1629 Charles I was so dissatisfied by his ill-fated attempt to secure a bill on tonnage and poundage ${ }^{16}$ that he did not summon another Parliament for the next 11 years-the period came to be known as the Personal Rule. Re-assembled once again in 1640, the Long Parliament marked a watershed in parliamentary history. Before and after this moment the Parliaments met only infrequently and for short sessions. Even after the Glorious Revolution never has any Parliament sat continuously for over 12 years with only a single short adjournment. Having abolished, first, the monarchy and, later, the House of Lords, it assumed many of the executive powers, previously reserved to the Crown. The Restoration Settlement of 1660 brought back a Stuart king, but the parliamentary agenda-setting power did not recede back to the pre-Civil War level. It gradually increased until the Glorious Revolution of 1688-89 brought about what became known as "parliamentary sovereignty", the era of parliamentary supremacy.

Figure 3 further illustrates the temporal evolution of the agenda-setting strategy exercised by parliamentarians. Plotted against the yearly number of passed parliamentary acts, our measure can be compared to the simple count of enacted laws in terms of convergent-divergent validity. Broadly speaking, entropy-based measure of agenda-setting

\footnotetext{
${ }^{16}$ Tonnage and poundage referred to a set of taxes levied on imported wine (tuns) and other merchandise, the right to which the Parliament had to grant on an annual basis.
} 


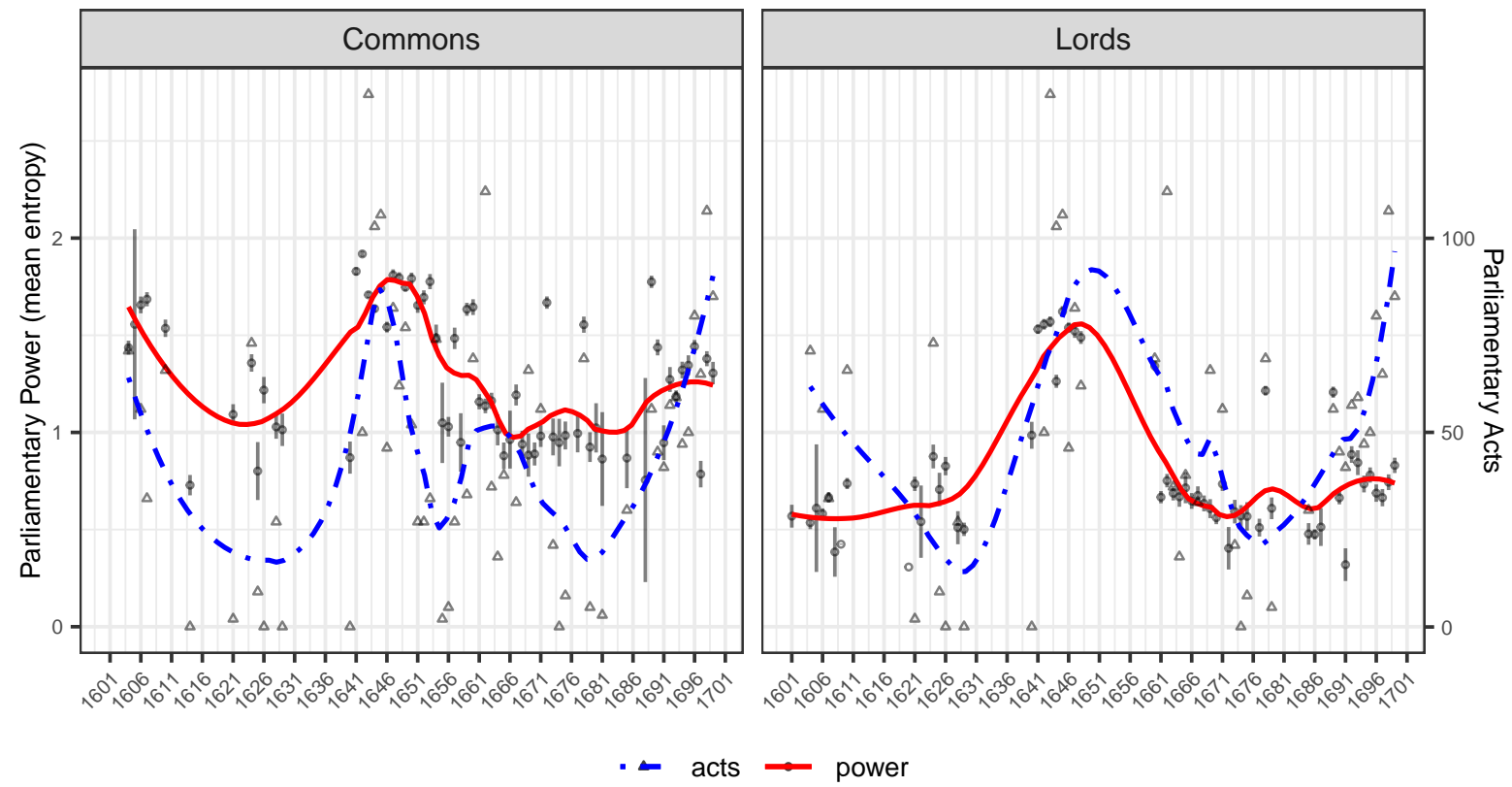

Note: The topic entropy estimates from LDA model with 10 topics are used. Sources of parliamentary acts counts: Firth and Rait (1911), Hoppit (1996) and Smith (1999).

closely follows the patterns of change in lawmaking in the seventeenth century. The reign of Charles I saw a gradual decline in parliamentary activity, with the onset of the Civil War in 1642 resulting in the dramatic rise in the topics covered by the House of Commons. During the year of Interregnum an important break happens at the end of 1653 following the inauguration of Oliver Cromwell as Lord Protector which once again limited parliamentarians agenda-setting strategy. The Restoration of monarchy further constrained parliamentarians' attention to different topics. It is worth noting, however, that there are important discrepancies between the two measures. The abrupt changes in the number of parliamentary acts is likely to reflect both genuine changes in the parliamentary power as well idiosyncratic factors of the Crown holder or a given year. It seems unlikely that the power dropped to exactly zero in years 1614, 1626, 1629 and 1640. Also, as already noted above, the sudden rise in the number of acts in the first years of Reconstruction reflected the need to replace the legislature passed by the Revolutionary Parliaments as 
opposed to any tangible increases in parliamentary power.

While behaving similar to extant measures of institutional power, our approach offers several advantages. First, by using topic entropy we are able to estimate MPs desire for power for all years, when the Parliament was in session, as opposed only to those years when legislation was passed. Notably, very few acts were passed in the 1670s (Hoppit, 1996). However, this period saw a gradual increase in the parliamentary strive for power that paved the way for the Glorious Revolution of 1688-1689 (Smith, 1999), a trend captured correctly by our measure. Second, it offers a smoother time trend which is closer to the notion of gradually evolving institutions and less likely to be affected by idiosyncratic variation. Third, our measure performs equally well across both Houses. And, fourth, the uncertainty estimates demonstrate how widely the documents from a given year vary in the estimated parliamentary agenda-setting strategy.

Overall, figure 3 is consistent with our theoretical expectations. During periods of heightened uncertainty-most notably during the revolutionary parliament, MPs strove to display their interest in a wider set of topics. In other words, political elites strategically exploited power voids to engage in an agenda-setting exercise in order to gain leverage over other actors and strengthen their position in the bargaining process.

\subsection{Policy Areas}

Did political elites present in the Parliament employ a specific set of topics during this agenda-setting exercise? What are the actual policy areas captured by the models? To understand this we can extract the words with the highest probability in each topic for some emblematic years of the seventeenth century. Table 2 shows the words with the highest probabilities for the topics whose proportion was larger than 0.05 in each case ${ }^{17}$. The number of topics extracted is per se instructive. While only one topic that consists almost entirely of procedural language was retained for the year 1625, eight topics passed

\footnotetext{
${ }^{17}$ We present only the results for the House of Commons here. Equivalent table for the House of Lords is available in Appendix D.
} 
this threshold in 1642, at the start of the Civil War, and 1689, the year when William of Orange was declared the King of England, Ireland and Scotland and the new era of parliamentary rule began.

Table 2: Top Words by Topic and Period.

\begin{tabular}{|c|c|c|}
\hline Topic & Proportion & Words \\
\hline \multicolumn{3}{|r|}{1625 (Useless Parliament) } \\
\hline Procedural & 0.828 & house committee king upon lords petition may tho edw jo \\
\hline \multicolumn{3}{|r|}{1642 (Civil War) } \\
\hline $\begin{array}{l}\text { Procedural I } \\
\text { Sovereignty } \\
\text { Legislative } \\
\text { Fiscal } \\
\text { Procedural II }\end{array}$ & $\begin{array}{l}0.208 \\
0.142 \\
0.121 \\
0.116 \\
0.103\end{array}$ & $\begin{array}{l}\text { lords house ordered concerning committee upon conference message appointed shall } \\
\text { shall parliament kingdom house arms houses commons persons time take } \\
\text { house petition answer lords committee concerning lord majesty ordered message } \\
\text { shall pounds ireland thousand hundred upon ordered unto monies committee } \\
\text { lords county order ordered upon earl read concerning forthwith sent }\end{array}$ \\
\hline \begin{tabular}{l|} 
Procedural III \\
Military \\
Crown
\end{tabular} & $\begin{array}{l}0.086 \\
0.072 \\
0.056\end{array}$ & $\begin{array}{l}\text { ordered committee house captain referred sent jo forthwith take wm } \\
\text { order ordered monies city army london house upon counties horses } \\
\text { majesty parliament majesty's may kingdom great shall king houses person }\end{array}$ \\
\hline \multicolumn{3}{|r|}{1662 (Restoration) } \\
\hline $\begin{array}{l}\text { Legislative } \\
\text { Procedural } \\
\text { Private }\end{array}$ & $\begin{array}{l}0.612 \\
0.156 \\
0.120\end{array}$ & $\begin{array}{l}\text { bill house committee read resolved ordered upon time day amendments } \\
\text { amendment read agreed question upon lords line second time conference } \\
\text { colonel john tho wm rich robert send robinson smith lord }\end{array}$ \\
\hline \multicolumn{3}{|r|}{1689 (Glorious Revolution) } \\
\hline $\begin{array}{l}\text { Legislative } \\
\text { Procedural } \\
\text { Private } \\
\text { Cameral } \\
\text { Crown }\end{array}$ & $\begin{array}{l}0.233 \\
0.151 \\
0.110 \\
0.086 \\
0.080\end{array}$ & $\begin{array}{l}\text { bill house read ordered upon leave committee time resolved act } \\
\text { house committee resolved bill speaker chair whole morning time ordered } \\
\text { john tho resolved wm lord rob colonel foley rich afternoon } \\
\text { lords conference commons house upon parliament agree king free laws } \\
\text { majesty address majesty's shall king ireland present kingdom majesties house }\end{array}$ \\
\hline $\begin{array}{l}\text { Local } \\
\text { Fiscal } \\
\text { Electoral } \\
\text { Judicial }\end{array}$ & $\begin{array}{l}0.080 \\
0.078 \\
0.070 \\
0.063\end{array}$ & $\begin{array}{l}\text { house ordered petition county member esquire serve borough custody arms } \\
\text { pounds hundred thousand revenue per king petition charles settling consideration } \\
\text { election parliament burgesses borough committee poll serve present read town } \\
\text { lord thomas justice house committee earl king's london court warrant }\end{array}$ \\
\hline
\end{tabular}

Note: Estimates derived from the House of Commons LDA model with 10 topics. Only topics with proportion higher than 0.05 are retained.

Towards the end of the seventeenth century we can identify specific topics pertaining to judicial and local matters. As the electoral process becomes more formalized, a new topic emerges that includes the types of constituencies (borough, county) used. Overall, the time around the Glorious Revolution provides a very good example of parliamentary sovereignty over a large number of, until then, rarely discussed policy domains that reflected the interests and appealed to broader classes of constituents. 


\subsection{State Capacity}

The expansion of the strive for parliamentary power should have some tangible implications for the functioning of a state. However, one concern could be that this relationship simply reflects the duration of Parliamentary sessions. To test whether our measure goes beyond simply capturing the amount of text generated, we fit linear regression models with the number of legislative acts as an outcome and mean topic entropy and the length of Parliamentary sittings as independent variables ${ }^{18}$. Models 1-3 in table 3 show the results. It appears that the duration of sessions is only weakly associated with the number of passed acts, while entropy-based measure is statistically significant across all specifications.

Table 3: Models Explaining Variation in the Number of Parliamentary Acts and Amount of Taxes Collected.

\begin{tabular}{|c|c|c|c|c|c|c|}
\hline & \multicolumn{3}{|c|}{ Acts (1604-1699) } & \multicolumn{3}{|c|}{$\log ($ taxes $)(1661-1688)$} \\
\hline & (1) & (2) & (3) & (4) & (5) & (6) \\
\hline Parliamentary Power & $\begin{array}{c}50.7017^{* * * *} \\
(11.4362)\end{array}$ & $\begin{array}{l}37.3423^{*} \\
(17.4642)\end{array}$ & $\begin{array}{c}47.0557^{*} \\
(18.0306)\end{array}$ & $\begin{array}{c}3.0987 \\
(1.8866)\end{array}$ & $\begin{array}{c}3.4777 \\
(1.8295)\end{array}$ & $\begin{array}{c}3.053 \\
(1.8405)\end{array}$ \\
\hline Days in sessions & & $\begin{array}{c}0.0512 \\
(0.0506)\end{array}$ & $\begin{array}{c}0.0786 \\
(0.0492)\end{array}$ & & $\begin{array}{c}-0.004 \\
(0.0026)\end{array}$ & $\begin{array}{c}-0.0047 \\
(0.0026)\end{array}$ \\
\hline Crown FE & & & $\checkmark$ & & & $\checkmark$ \\
\hline Constant & $\begin{array}{c}-20.3668 \\
(15.4896)\end{array}$ & $\begin{array}{c}-12.9864 \\
(17.1173) \\
\end{array}$ & & $\begin{array}{c}8.4508^{* * *} \\
(1.9412)\end{array}$ & $\begin{array}{c}8.7432^{* * *} \\
(1.8754)\end{array}$ & \\
\hline Observations & 55 & 55 & 55 & 20 & 20 & 20 \\
\hline$R^{2}$ & 0.27 & 0.28 & 0.82 & 0.13 & 0.24 & 0.99 \\
\hline
\end{tabular}

Note: All models are estimated using OLS. Standard errors are reported in parentheses. Only direct and indirect taxation authorized by the Parliament is included. This excludes Crown's own sources of income such as its lands or feudal dues. The amount of taxes collected is based on the calculations by Chandaman (1975).

As one of the critical roles of earlier representative assemblies was authorizing various taxes, we would anticipate a link between parliamentary power and the amount of taxes

\footnotetext{
${ }^{18}$ Ideally, to account for potential exogenous changes to agenda we would prefer a model with year fixed effects. However, fitting any such model requires the availability of outcome variables measured at subyear level, which are, unfortunately, unavailable for this period. Thus, we slightly relax this assumption, presuming that any such change coincided with a change of a reigning monarch, and fit all models with Crown-level fixed effects.
} 
raised. Indeed, one of the first urgent tasks that the Revolutionary Parliament faced was raising money to establish the New Model Army. Unfortunately, as is often the case for so early a period, the data on the amount of taxes raised in the seventeenth century is scant. The earliest consistent figures are available for the Restoration period (Chandaman, 1975). Bearing in mind that any estimates for this era should be taken with a grain of salt, Models 4-6 in table 3 show the coefficients of our measure on the logarithm of taxes raised. As expected, the coefficient of our agenda-setting measure shows positive association both with and without control for the duration of sessions in these years. However, given the limited number of years for which data on taxation is available, this association is not statistically significant.

\section{Alternative Explanations}

As we empirically demonstrate above, MPs engaged in an agenda-setting exercise in order to demonstrate that the Parliament was ready to exercise sovereignty over the realm. With an eye on both the monarch and on their constituents, parliamentarians strategically started covering of a wider set of topics during power voids, thus, increasing their pressure on the monarch and presenting themselves as the logical rulers. In this section we discuss several potential alternative explanations to our argument. Despite the lack of data preventing us from directly testing those, we argue that none of these explanations provides a satisfactory account of the observed increases in the agendasetting power as measured by topic entropy.

The first potential threat to our theory is that a change in the composition of the houses might have resulted in an increase in the number of topics covered by them. If there was a change in parliamentarians' geographical provenance, or in their social class, this would have brought a different set of ideological preferences to the Parliament and hence new topics. One might argue that a wider set of issues emerged when the houses represented broader social strata and not as a conscious strategy pursued by elites. 
Regarding the geographical diversity of MPs, changes in the composition of the English Parliament during the seventeenth century did not cover substantially new territories, simply because both the House of Commons and the House of Lords were already a genuinely national assembly at the start of the century and the largest representative body in Europe (Stasavage, 2020). In fact, the most important change in the geographical coverage took place in the last decades of the sixteenth century due to the extension of the franchise to fourteen previously unrepresented counties in Wales-a total of twelve shires. Otherwise, most changes happened after new boroughs in counties that already sent representatives to Westminster were created or after a change in borders in existing boroughs (Thrush and Ferris, 2010).

As for membership, it indeed changed over time, but it kept a few core characteristics throughout our period of interest. The social profile of the members of the Commons shows that MPs were mainly drawn from the ranks of the ruling elite. For instance, if we look at parliamentarians before the Civil War, at least half attended the universities of Oxford or Cambridge, and more than half of the lawyers present in the house-one of the largest social groups-came from the Inns of Court or Inns of Chancery (Thrush and Ferris, 2010). Bearing in mind that they came from the ruling elite, MPs represented a diverse range of social and economic backgrounds. Peers represented the traditional aristocracy, but occasionally also rich yeomen or even men of relatively humble stock. However, crucially for our argument, the information gathered by historians shows that, if anything, changes in the composition were mainly due to James' and Charles' efforts to broaden their influence through the increase in the number of deputies through honoursthat is, granting a position to sons or brothers of peers. These new members naturally had little incentives to engage in a strategy that eroded the king's power.

This logic is especially pronounced in the House of Lords. To sit in the House, most of them required a personal permission from the monarch. In fact, on the eve of the Civil War, Stuart appointments represented $66.6 \%$ of the peerage in the Lords. Crucially, even when we analyze the entropy levels for a more regulated body like the House of Lords, 
our results are empirically similar to the Commons. This is interesting as it shows that monarchs gradually lost political control of the Lords (Stasavage, 2020) and that even attempts to control its composition did not result in a complete erosion of the political will of the chamber.

Unlike the Lords, the Commons experienced continued growth. At the beginning of the sixteenth century there were 296 seats, but by 1629 this number had risen to 493, an increase of more than $65 \%$. Before 1621 the power to enlarge the House laid largely with the Crown and it is precisely when the growth took place ${ }^{19}$. And the large increase in new positions in the House of Commons occurred a decade before the Civil War. This implies that the most important changes in the composition of the Commons happened decades before the most significant power voids, which rules out the idea that the Commons created a substantial number of new positions as a way of galvanizing more support. Our results show that entropy levels in the first decades of the sixteenth century, when the Commons was enlarged, were relatively low.

An alternative way to capture changes in the composition of the Parliament is to examine the patterns of surname distributions over time. Fluctuations in the distribution of surnames across the different parliaments, if such variation exists, should be uncorrelated with our measure of power. In case both are correlated, it would provide indirect evidence that changes in power may be driven by significant changes in the composition of the House of Commons and not by MPs' conscientious decision to set the agenda. We collected the names of all members of the House of Commons in the XVII century and calculated a surname diversity index (Prost et al., 2008). This index calculates, for each parliament, the ratio between the number of unique surnames and the logarithm of the total number of MPs. Thus, as the surname diversity increases, the value of this index also goes up. Figure 4 shows the evolution of surname diversity over time. It also includes our measure of parliamentary power for comparison. As can be seen from the graph, there is no relationship between the two - the correlation between the two is $0.06(p=0.78)$.

\footnotetext{
${ }^{19}$ It is important to note that new political positions represented a way of patronage (Smith, 1999)
} 
As is also evident from the figure there is no discernible temporal lag between the two measures. All in all, we contend that changes in the composition of both chambers are unlikely to drive the increase of entropy levels during power voids.

Figure 4: MPs' Surname Diversity Over Time.

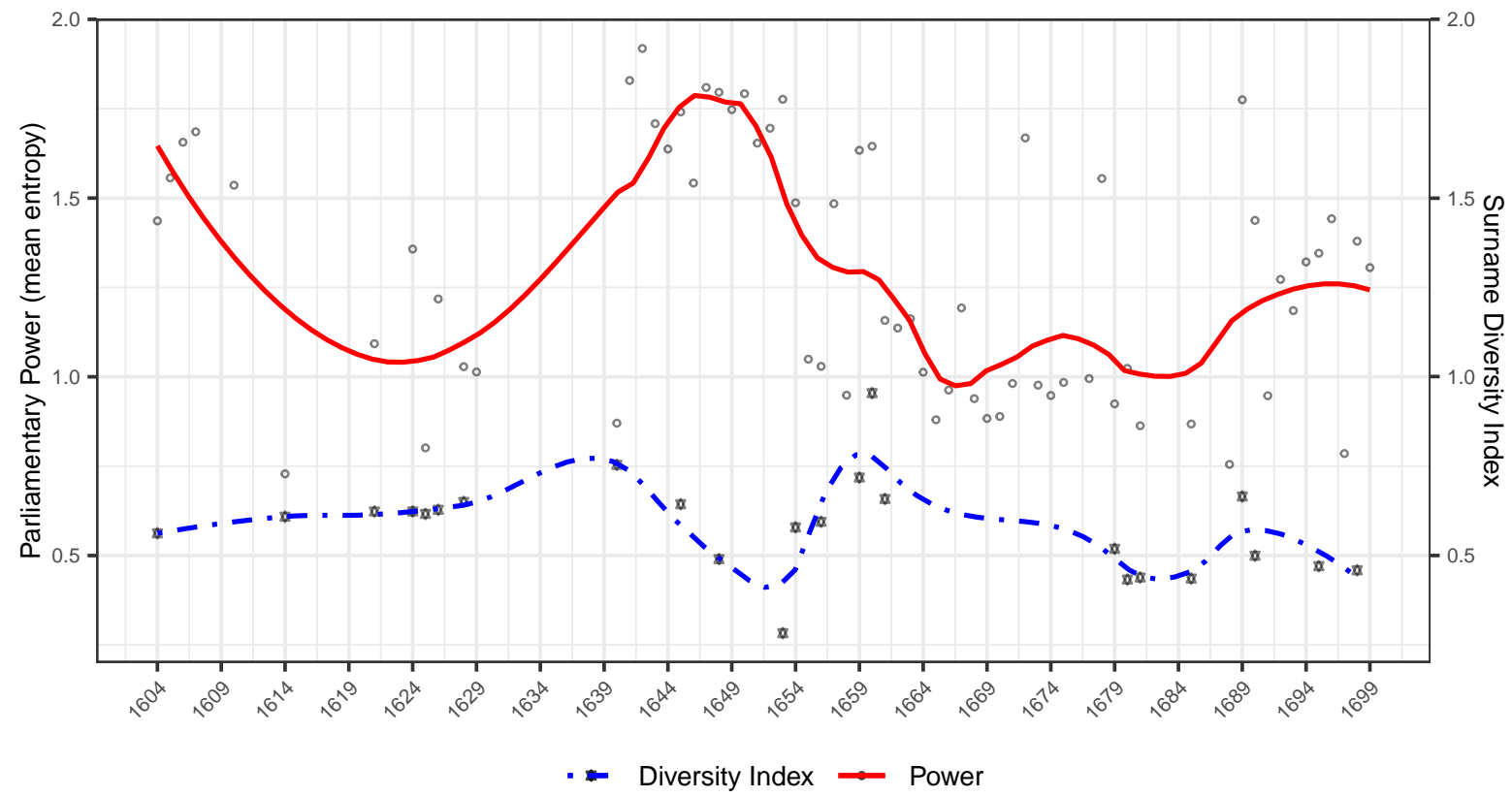

Note: The topic entropy estimates from LDA model for the House of Commons with 10 topics are used.

The second counter-argument to consider concerns potential changes in the dominant political groups within the Commons over time, especially during the key power voids. One might argue that it is precisely when political allegiances changed that we observe an increase in entropy levels as the new majority could have potentially brought a new or more diverse set of topics on the political agenda. Despite political allegiances in the Parliament indeed changed during the seventeenth century, we believe they alone were insufficient to drive the variation in the level of entropy during power voids. First, it is problematic to assume that new political allegiances in parliament inevitably pushed the parliament to focus on a wider set of topics. As historians have shown, agreements were rather short and often formed to adopt specific bills-and not a bundle of measures (Smith, 1999). Second, despite the existence of informal groups, there were no politi- 
cal parties that could easily enforce cohesion. 'Party' discipline was weak and divisions within 'party' lines were common. One of the best examples is, perhaps, the controversies over the New Model Army and the Self-Denying Ordinance in 1645, which established a centrally-controlled military force and prohibited members of either house to hold military commands. Presbyterians, the largest faction in the Commons, were against it. However, a significant faction of 'peace party' Presbyterians soon broke with their colleagues and resigned their military positions to retain their political powers. Thus, even the cohesion of the Presbyterians block, one of the most important ones in the chamber, was relatively weak. Third, as historians generally argue, during most of the century "party divisions counted for little: there were factions, groups or individuals trying to re-insure against any eventuality" (Hill, 1980, 278). Party labels-Whigs and Tories-became popular only at the end of the century and, although members of each party shared some ideological principles, party loyalty only became the norm almost two centuries later (Cox, 1987). Finally, seventeenth century England was characterized by a series of cleavages that cut across factions and groups. Many debates revolved around the role of religion and economic matters-such as taxes on exports or the control of public monopolies. Other conflicts simply arose with the goal of controlling distribution of the spoils of office and hence creating a different system of patronage (Hill, 1980; Peck, 1993). All in all, it is unlikely that we observe an increase in topic diversity during power voids as allegiances in the Parliament changed over time both during critical periods and during the majority of the seventeenth century.

Finally, we have also explored whether parliamentarians increased their attention to a wider set of topics as a result of pressures from below. In other words, MPs could have changed their strategy when they observed that people expressed different preferences or brought new issues into the parliamentary floor. We explore this possibility through an analysis of the text of petitions (see Appendix G.6). The analysis includes 2,063 petitions sent to the Parliament between 1600 and 1700. 


\section{Conclusions}

In this article we propose that political elites in early representative assemblies complemented their demand for power by engaging in an agenda-setting exercise during periods of political uncertainty. Thus, when a power void occurred, parliamentarians strove to set the political agenda by manifesting their preference towards a wider variety of topics. MPs engaged in an agenda-setting exercise in order to strengthen their bargaining position and ultimately gain the upper hand in the negotiations with the monarch.

In order to test our argument, our main analysis is based on the text included in the Journals of the House of Commons and the House of Lords covering the period between the sixteenth and the early eighteenth century. This offers a novel way to examine the behavior of parliamentary elites during the key period in the history of the English Parliament, when both the Commons and the Lords were still finding its political and institutional position vis-à-vis the monarchy. We also develop a measure of desire for institutional power based on a topic entropy indicator built using the LDA model. As we show, this method allows us to capture how political elites behave and study the political strategy employed by parliamentarians during the bargaining process with the monarch. Our approach suggests that even records from earlier periods of institutional history can provide a rich source of data for studies using modern text analysis methods.

Overall, our results offer a more nuanced view of the bargaining process between the monarch and the Parliament and shed light on a complimentary strategy parliamentarians employed to gain leverage in the negotiation process. Our findings align well with the idea that early parliaments grew in contexts in which institutions were weak (Stasavage, 2020). We complement this theoretical insights by showing how elites exploited power voids to their own advantage.

Although this article has put our theoretical intuition to the empirical test in the context of the seventeenth-century England, one might extend it to other early representative assemblies across Europe. The same logic can even be applied to some contemporaneous 
representative institutions. Today, there exists a myriad of political institutions that have limited powers and whose elites constantly seek to increase their influence on a wider set of issues. For instance, elites in many regional parliaments, especially those in stateless nations, may engage in a similar agenda-setting behavior in an attempt to become the political reference point of their constituents-voters in the region-, as well as to put pressure on central institutions in order to negotiate a devolution of power. The same elite behavior could also be present in other institutions, such as in the European Union or in other transnational organizations. Future works could apply the logic explored in our paper to modern institutions and, with speech data and metadata available for all MPs, examine the political groups that are more likely to engage in such behavior.

Overall, our article complements the existing and influential bargaining model and lays ground to a new way of analyzing the behavior of political elites in early representative assemblies, which may ultimately help us better understand the rise and fall of modern parliaments. 


\section{References}

Abramson, Scott F and Carles Boix (2019). Endogenous Parliaments: The Domestic and International Roots of Long-Term Economic Growth and Executive Constraints in Europe. International Organization 73(4), 793-837.

Acemoglu, Daron (2005). Politics and economics in weak and strong states. Journal of Monetary Economics 52(7), 1199-1226. Political economy and macroeconomics.

Acemoglu, Daron, Simon Johnson, and James A. Robinson (2005). Chapter 6 Institutions as a Fundamental Cause of Long-Run Growth. Volume 1 of Handbook of Economic Growth, pp. 385 - 472. Elsevier.

Aidt, Toke S. and Raphaël Franck (2019). What Motivates an Oligarchic Elite to Democratize? Evidence from the Roll Call Vote on the Great Reform Act of 1832. The Journal of Economic History 79(3), 773-825.

Barberá, Pablo , Andreu Casas, Jonathan Nagler, Patrick J. Egan, Richard Bonneau, John T. Jost, and Joshua A. Tucker (2019). Who Leads? Who Follows? Measuring Issue Attention and Agenda Setting by Legislators and the Mass Public Using Social Media Data. American Political Science Review 113(4), 883-901.

Benoit, Kenneth , Michael Laver, and Slava Mikhaylov (2009). Treating Words as Data with Error: Uncertainty in Text Statements of Policy Positions. American Journal of Political Science 53(2), 495-513.

Blei, David M , Andrew Y Ng, and Michael I Jordan (2003). Latent Dirichlet Allocation. Journal of Machine Learning Research 3, 993-1022.

Blumenau, Jack (2021). The Effects of Female Leadership on Women's Voice in Political Debate. British Journal of Political Science 51(2), 750-771. 
Boix, Carles (2015). Political Order and Inequality: Their Foundations and their Consequences for Human Welfare. Cambridge Studies in Comparative Politics. Cambridge University Press.

Bond, Maurice F (1971). Guide to the Records of Parliament. London: Her Majesty's Stationery Office.

Boucoyannis, Deborah (2015). No Taxation of Elites, No Representation: State Capacity and the Origins of Representation. Politics 8 Society 43(3), 303-332.

Boucoyannis, Deborah (2021). Kings as Judges: Power, Justice, and the Origins of Parliaments. Cambridge: Cambridge University Press.

Chandaman, C D (1975). The English Public Revenue, 1660-1688. Oxford: Clarendon Press.

Cogswell, Thomas (1990). A Low Road to Extinction? Supply and Redress of Grievances in the Parliaments of the 1620s. The Historical Journal 33(2), 283-303.

Cox, Gary W. (1987). The Efficient Secret: The Cabinet and the Development of Political Parties in Victorian England. Political Economy of Institutions and Decisions. Cambridge University Press.

Cox, Gary W. (2017). Political Institutions, Economic Liberty, and the Great Divergence. The Journal of Economic History $77(3)$, 724-755.

De Long, J. Bradford and Andrei Shleifer (1993). Princes and Merchants: European City Growth before the Industrial Revolution. The Journal of Law and Economics 36(2), $671-702$.

Dincecco, Mark (2015). The Rise of Effective States in Europe. The Journal of Economic History $75(3), 901-918$. 
Eggers, Andrew C. and Arthur Spirling (2014). Ministerial Responsiveness in Westminster Systems: Institutional Choices and House of Commons Debate, 1832-1915. American Journal of Political Science 58(4), 873-887.

Eggers, Andrew C. and Arthur Spirling (2018). The Shadow Cabinet in Westminster Systems: Modeling Opposition Agenda Setting in the House of Commons, 1832 - 1915. British Journal of Political Science 48(2), 343-367.

Firth, C H and R S Rait (1911). Acts and Ordinances of the Interregnum, 1642-1660, Vol. I-III. London: His Majesty's Stationery Office.

Fryde, E B , D E Greenway, S Porter, and I Roy (Eds.) (1986). Handbook of British Chronology (3rd ed.). London: Royal Historical Society.

Greif, Avner and David D Laitin (2004). A Theory of Endogenous Institutional Change. American Political Science Review 98(4), 633-652.

Griffiths, Thomas L. and Mark Steyvers (2004). Finding Scientific Topics. Proceedings of the National Academy of Sciences 101 (suppl 1), 5228-5235.

Grimmer, Justin and Brandon M Stewart (2013). Text as Data: The Promise and Pitfalls of Automatic Content Analysis Methods for Political Texts. Political Analysis 21(3), $267-297$.

Gruenfelder, John K. (1981). Influence in Early Stuart Elections, 1604-1640. Columbus: Ohio State University Press.

Hall, David , Daniel Jurafsky, and Christopher D Manning (2008). Studying the History of Ideas Using Topic Models. In Proceedings of the 2008 Conference on Empirical Methods in Natural Language Processing, pp. 363-371.

Hariri, Jacob Gerner (2012). The Autocratic Legacy of Early Statehood. American Political Science Review 106(3), 471-494. 
Harriss, Gerald L. (1976). War and the Emergence of the English Parliament, 1297-1360. Journal of Medieval History 2(1), 35-56.

Herb, Michael (2003). Taxation and Representation. Studies in Comparative International Development 38(3), 3 .

Hill, Christopher (1980). The Century of Revolution, 1603-1714. New York: Norton.

Hoppit, Julian (1996). Patterns of Parliamentary Legislation, 1660-1800. The Historic Journal 39(1), 109-131.

Hoppit, Julian (2017). Britain's Political Economies: Parliament And Economic Life, 1660-1800. Cambridge: Cambridge University Press.

Lauderdale, Benjamin E. and Tom S. Clark (2014). Scaling Politically Meaningful Dimensions Using Texts and Votes. American Journal of Political Science 58, 754-771.

Levi, Margaret (1981). The Predatory Theory of Rule. Politics $\&$ Society 10 (4), 431-465.

Levi, Margaret (1989). Of Rule and Revenue. Berkeley: University of California Press.

Lippmann, Walter (1922). Public Opinion. New York, NY: Harcourt, Brace and Company.

McCombs, Maxwell E. and Donald L. Shaw (1972). The Agenda-Setting Function of Mass Media. The Public Opinion Quarterly 36(2), 176-187.

Møller, Jørgen (2017). The Birth of Representative Institutions: The Case of the Crown of Aragon. Social Science History 41(2), 175-200.

North, Douglass C. (1990). Institutions, Institutional Change and Economic Performance. Political Economy of Institutions and Decisions. Cambridge University Press.

North, Douglass C. and Robert Paul Thomas (1973). The Rise of the Western World: A New Economic History. Cambridge University Press. 
North, Douglass C and Barry R Weingast (1989). Constitutions and Commitment: The Evolution of Institutions Governing Public Choice in Seventeenth-Century England. The Journal of Economic History XLIX(4), 803-832.

Peck, Linda Levy (1993). Court Patronage and Corruption in Early Stuart England. London: Routledge.

Prost, M. , G. Boëtsch, M. Girotti, and E. Rabino-Massa (2008). Surname Analysis in Biological Anthropology: Alpine Populations in the 17th and 18th Centuries. Human Biology 80(4), $377-391$.

Puga, Diego and Daniel Trefler (2014). International Trade and Institutional Change: Medieval Venice's Response to Globalization. The Quarterly Journal of Economics 129(2), $753-821$.

Raymond, Joad (1998). The Newspaper, Public Opinion, and the Public Sphere in the Seventeenth Century. Prose Studies 21(2), 109-136.

Rogers, Everett M. and James W. Dearing (1988). Agenda-Setting Research: Where Has It Been, Where Is It Going? Annals of the International Communication Association 11(1), 555-594.

Ruck, Damian J. , Luke J. Matthews, Thanos Kyritsis, Quentin D. Atkinson, and R. Alexander Bentley (2020). The cultural foundations of modern democracies. Nature Human Behaviour 4(3), 265-269.

Russell, Conrad (1976). Parliamentary History in Perspective, 1604-1629. History $61(201), 1-27$.

Russell, Conrad (1990). Unrevolutionary England, 1603-1642. London: The Hambledon Press.

Shannon, Claude E (1948). A Mathematical Theory of Communication. Bell System Technical Journal 27(3), 379-423. 
Sharpe, Kevin (1986). Crown, Parliament and Locality: Government and Communication in Early Stuart England. The English Historical Review 101 (399), 321-350.

Smith, David L (1999). The Stuart Parliaments: 1603-1689. London: Arnold.

Stasavage, David (2010). When Distance Mattered: Geographic Scale and the Development of European Representative Assemblies. American Political Science Review $104(4), 625-643$.

Stasavage, David (2016). Representation and Consent: Why They Arose in Europe and Not Elsewhere. Annual Review of Political Science 19(1), 145-162.

Stasavage, David (2020). The Decline and Rise of Democracy: A Global History from Antiquity to Today. Princeton, NJ: Princeton University Press.

Thrush, Andrew and John P Ferris (Eds.) (2010). The House of Commons 1604-1629, Vol. I-VI. Cambridge: Cambridge University Press.

Tilly, Charles (Ed.) (1975). The Formation of National States in Western Europe. Princeton, N.J.: Princeton University Press.

Van Zanden, Jan Luiten, Eltjo Buringh, and Maarten Bosker (2012). The rise and decline of European parliaments, 1188-1789. Economic History Review 65(3), 835-861.

Zaret, David (1996). Petitions and the "Invention" of Public Opinion in the English Revolution. American Journal of Sociology 101(6), 1497-1555. 


\section{Appendix}

Parliament Strikes Back: Agenda-setting and Power Voids in Early Representative Assemblies

\section{Contents}

A Parliamentary Journals 2

$\begin{array}{ll}\text { B Contested Elections } & 3\end{array}$

C Latent Dirichlet Allocation $\quad 4$

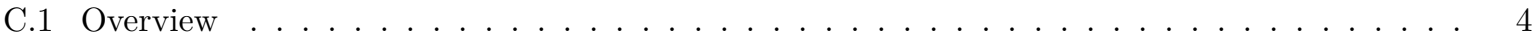

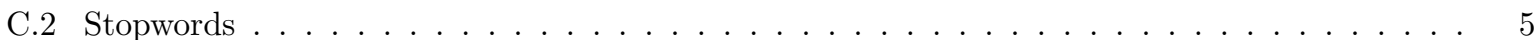

C.3 Topic Diagnostic . . . . . . . . . . . . . . . . . . . . . . . . . . 6

C.4 Robustness Tests . . . . . . . . . . . . . . . . . . . . . . . . 7

$\begin{array}{ll}\text { D House of Lords Topics } & 8\end{array}$

$\begin{array}{llr}\text { E Legislative Acts Topics } & 9\end{array}$

F Lagged Models of Power $r$

G Additional Results $\quad 11$

G.1 Parliamentary Power Trends $(16-17$ cc.) . . . . . . . . . . . . . . . . . . . 11

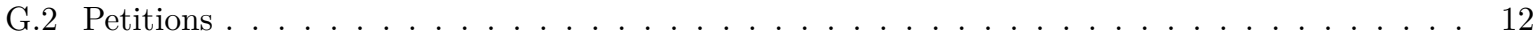

G.3 Mentions of Magna Carta . . . . . . . . . . . . . . . . . . . . . . . . 13

G.4 Identifying Power Voids . . . . . . . . . . . . . . . . . . . . . . . . . . . . . . 14

$\begin{array}{lr}\text { H Software Statement } & 16\end{array}$

$\begin{array}{lr}\text { References } & 17\end{array}$ 


\section{A Parliamentary Journals}

An example page in figure A.1 shows the original scan of the Parliamentary Journal of the House of Commons, documenting the start of the First English Civil War.

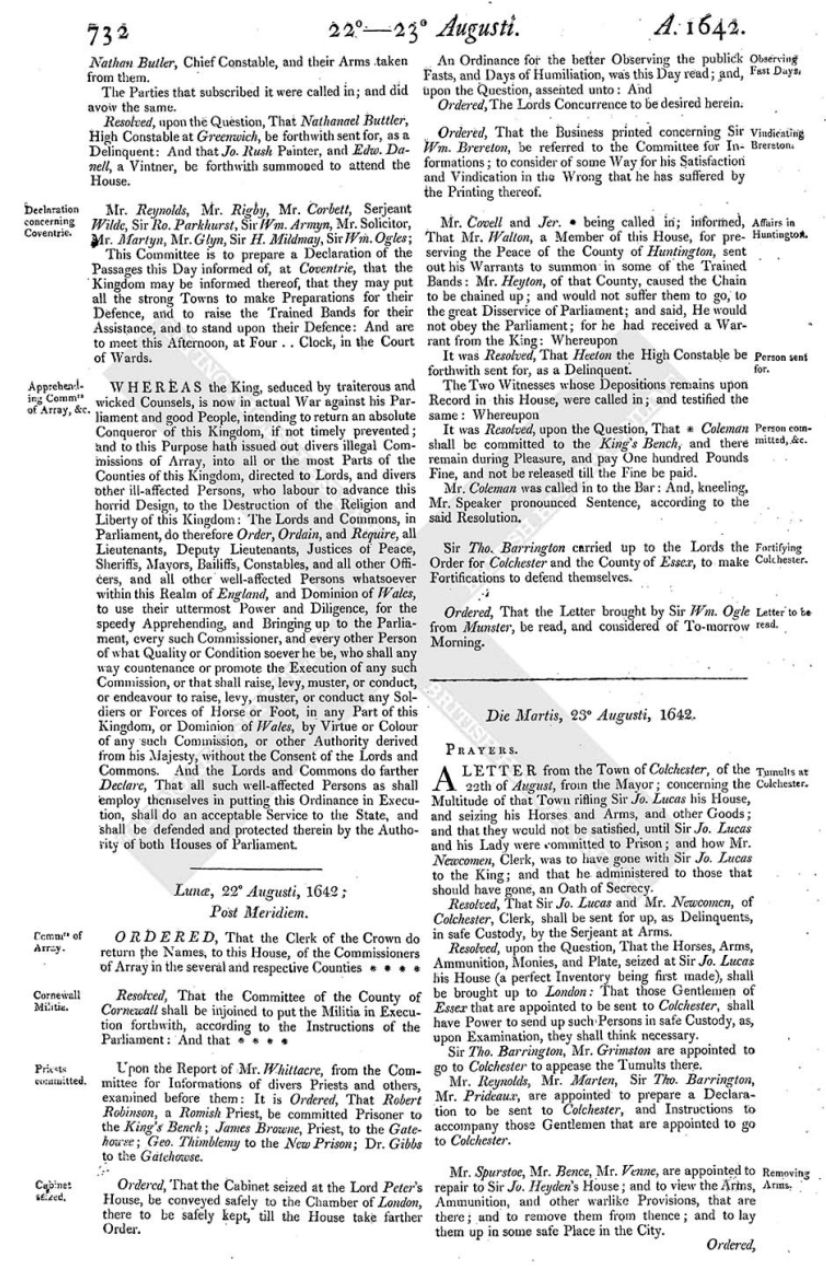

Figure A.1: Example page from Parliamentary Journals 


\section{B Contested Elections}

Figure B.2 shows the evolution of the number of contested elections over time. As we explain in the manuscript, contested elections followed an upward trend since the beginning of the XVII century. As explained by historians, MPs increasingly faced a larger audience and the need to broaden their appeal to their constituents. Power voids gave MPs a window of opporuntity, which implied, as we show in the article, that they started to cover a wider set of issues. This strategy was not only seeking to put pressure to the monarch, but also to show to constituents that they were ready to start governing the matters of the realm and that their policies would be more beneficial to constituents than those implemented by the monarch.

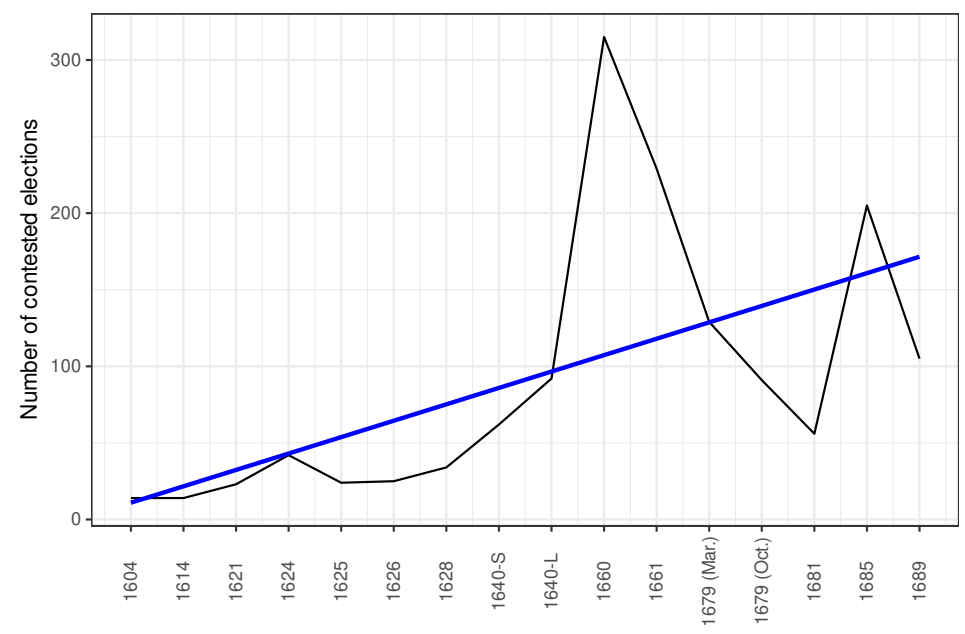

Figure B.2: Number of contested elections (XVII century)

Sources: 1604-1640(L): Hirst (1975); 1660-1689: Henning (1983), available at the History of Parliament website 


\section{Latent Dirichlet Allocation}

\section{C.1 Overview}

The roots of Latent Dirichlet allocation (LDA) lie in latent semantic indexing (LSI), a technique developed by Deerwester et al. (1990) to improve the performance of information retrieval systems by deriving latent semantic structure of a set of documents. This is achieved by using singular-value decomposition to estimate a reduced number (50-100 for thousands of words and documents) of orthogonal factors or dimensions and then treating those as latent semantic space to calculate document and word similarity. Hofmann (1999) extended the model by introducing a probabilistic model to the, otherwise, linear algebra transformation. LDA, developed by Blei, Ng, and Jordan (2003) is a full Bayesian implementation of the probabilistic LSI. Another way to look at is as a hierarchical Bayesian mixed-membership model, where each document $i$ is a finite mixture of underlying topics, with proportions $\theta_{i}$ drawn from Dirichlet prior. For each word $w_{i j}$ a topic assignment $z_{i}$ comes from a mixture of topic probabilities with multinomial prior and, conditional on it and term distribution of topics $\beta$ (the probability of a word occurring in a given topic), a word is drawn from a multinomial prior:

$$
\begin{gathered}
\boldsymbol{\theta} \sim \operatorname{Dirichlet}(\alpha) \\
z_{i} \sim \operatorname{Multinomial}(\boldsymbol{\theta}) \\
w_{i j} \sim \operatorname{Multinomial}\left(p\left(w_{i j} \mid z_{i}, \boldsymbol{\beta}\right)\right)
\end{gathered}
$$

The key analytical choices that the fit of LDA requires are the choice of $k$, the number of topics, which assumed to be known a priori and fixed and the concentration parameter $\alpha$, which controls the prior distribution of topic proportions. We fit LDA model with topicmodels package (Grün and Hornik 2011) using collapsed Gibbs sampling (Griffiths and Steyvers 2004; Phan, Nguyen, and Horiguchi 2008) with Dirichlet prior $\alpha$ set at 5 . 


\section{C.2 Stopwords}

Table C.1 shows the stopwords removed from the Journals prior to fitting LDA model. It includes both frequent contemporary English words as well as single letters (often used for indexing) and some Latin words, such as names of days and months.

Table C.1: English and Latin Stopwords Removed from the Corpora

\begin{tabular}{|c|c|c|c|c|c|c|c|c|c|}
\hline $\mathrm{a}$ & below & each & hers & januarii & novembris & saturni & then & wasn't & won't \\
\hline about & between & $\mathrm{f}$ & herself & julii & $\mathrm{O}$ & septembris & there & we & would \\
\hline above & both & februarii & him & junii & octobris & shan't & there's & we'd & wouldn't \\
\hline after & but & few & himself & $\mathrm{k}$ & of & she & these & we'll & $\mathrm{x}$ \\
\hline again & by & for & his & 1 & off & she'd & they & we're & $\mathrm{y}$ \\
\hline against & $\mathrm{c}$ & from & how & let's & on & she'll & they'd & we've & you \\
\hline all & can't & further & how's & lunae & once & she's & they'll & were & you'd \\
\hline $\mathrm{am}$ & cannot & g & $\mathrm{i}$ & $\mathrm{m}$ & only & should & they're & weren't & you'll \\
\hline an & could & $\mathrm{h}$ & i'd & maii & or & shouldn't & they've & what & you're \\
\hline and & couldn't & had & i'll & martii & other & $\operatorname{sir}$ & this & what's & you've \\
\hline any & d & hadn't & i'm & martis & ought & so & those & when & your \\
\hline aprilis & decembris & has & i've & me & our & solis & through & when's & yours \\
\hline are & $\operatorname{did}$ & hasn't & if & mercurii & ours & some & to & where & yourself \\
\hline aren't & didn't & have & in & more & ourselves & such & too & where's & yourselves \\
\hline as & die & haven't & into & most & out & $\mathrm{t}$ & $\mathrm{u}$ & which & $\mathrm{Z}$ \\
\hline at & do & having & iovis & $\mathrm{mr}$ & over & than & under & while & \\
\hline augusti & does & he & is & mustn’t & own & that & until & who & \\
\hline $\mathrm{b}$ & doesn't & he'd & isn't & my & $\mathrm{p}$ & that's & up & who's & \\
\hline be & doing & he'll & it & myself & q & the & $\mathrm{v}$ & whom & \\
\hline because & don't & he's & it's & $\mathrm{n}$ & $\mathrm{r}$ & their & veneris & why & \\
\hline been & down & her & its & no & $\mathrm{s}$ & theirs & very & why's & \\
\hline before & during & here & itself & nor & said & them & $\mathrm{w}$ & will & \\
\hline being & e & here's & $\mathrm{j}$ & not & same & themselves & was & with & \\
\hline
\end{tabular}




\section{C.3 Topic Diagnostic}

While recognizing the inherent trade-off between semantic interpretability and statistical fit (Chang et al. 2009), we check the adequacy of our substantive choice of the number of topics as presented in the main text. We fit LDA model using topicmodels package (Grün and Hornik 2011) on the entire corpus combining parliamentary records from all years with different number of topics, ranging between 5 and 100 and compare estimated log-likelihood and perplexity. We do 10-fold cross-validation to calculate perplexity on a held-out corpus. In addition we calculate bootstrapped standard errors for both statistics. Conceptually, perplexity can be viewed as geometric average per-word likelihood. We calculate it as follows:

$$
\operatorname{Perplexity}(w)=\exp \left\{-\frac{\log (p(w))}{\sum_{d=1}^{D} \sum_{j=1}^{V} n^{(j d)}}\right\}
$$

Where $n^{(j d)}$ denotes how often a term $j$ occurs in document $d$ and the word likelihood is determined as:

$$
\log (p(w))=\sum_{d=1}^{D} \sum_{j=1}^{V} n^{(j d)} \log \left[\sum_{k=1}^{K} \theta_{k}^{(d)} \beta_{k}^{(j)}\right]
$$

Figure B.2 shows the estimates for the Journals of the House of Commons and figure C.3 presents analogous statistics for the House of Lords. Two models, in particular, are worth noting. The model with 10 topics offers the most significant improvement in statistical fit for a fixed step. At the same time the model with 30 topics offers the best statistical fit, beyond which we do not observe any further improvement as we continue to increase the number of topics. As a more conservative choice to avoid overfitting, as well as to ease the substantive interpretation of the generated topics, we chose to present the results using the model with 10 topics in the main text of the article. However, as we show in the section below, the main results hold under a more data-driven choice of the parameter $k$.
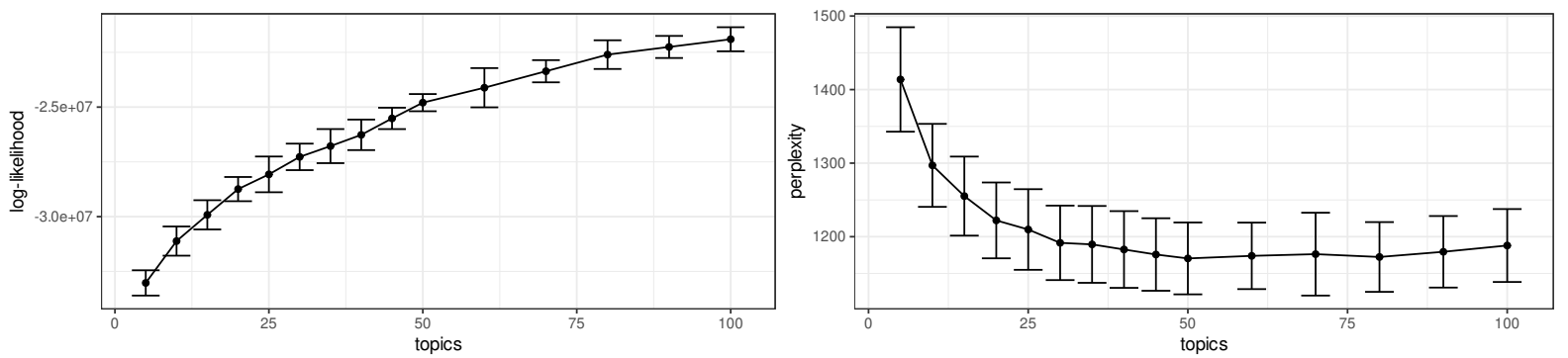

Figure C.3: House of Commons LDA Diagnostics
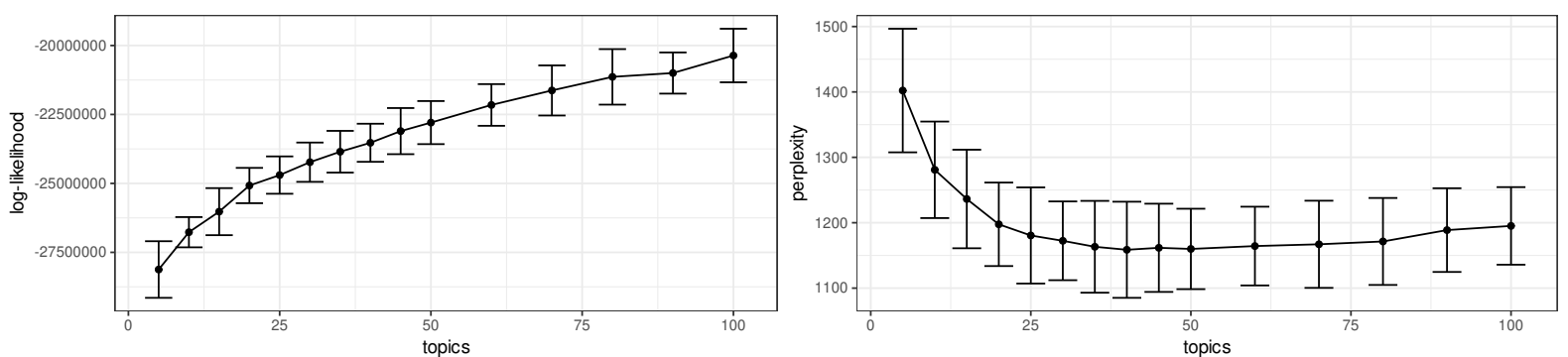

Figure C.4: House of Lords LDA Diagnostics 


\section{C.4 Robustness Tests}

As a robustness test, we show the main results, presented in table 3 of the main text, replicated using the mean yearly topic entropies, estimated using LDA model with $k=30$. As table C.2 demonstrates, positive and significant association between the estimated parliamentary power and the number of yearly passed acts remains consistent across models with a different number of topics. The results for taxes appear to be somewhat more sensitive, however, the limited sample size is the most likely reason for the observed changes.

Table C.2: Models Explaining Variation in the Number of Parliamentary Acts and Amount of Taxes Collected $(\mathrm{k}=30)$

\begin{tabular}{|c|c|c|c|c|c|c|}
\hline & \multicolumn{3}{|c|}{ Acts (1604-1699) } & \multicolumn{3}{|c|}{$\log ($ taxes $)(1661-1688)$} \\
\hline & (1) & $(2)$ & (3) & (4) & (5) & (6) \\
\hline Parliamentary Power & $\begin{array}{c}38.5159^{* *} \\
(13.4358)\end{array}$ & $\begin{array}{c}10.5817 \\
(16.9851)\end{array}$ & $\begin{array}{l}44.5704^{*} \\
(18.0176)\end{array}$ & $\begin{array}{c}0.4096 \\
(1.9027)\end{array}$ & $\begin{array}{c}1.1032 \\
(1.9343)\end{array}$ & $\begin{array}{c}-0.6112 \\
(2.2853)\end{array}$ \\
\hline Days in sessions & & $\begin{array}{c}0.1142^{*} \\
(0.0456)\end{array}$ & $\begin{array}{c}0.1127^{* *} \\
(0.0419)\end{array}$ & & $\begin{array}{c}-0.0038 \\
(0.0029)\end{array}$ & $\begin{array}{c}-0.0042 \\
(0.0028)\end{array}$ \\
\hline Crown FE & & & $\checkmark$ & & & $\checkmark$ \\
\hline Constant & $\begin{array}{l}-37.7648 \\
(29.5669)\end{array}$ & $\begin{array}{c}0.4393 \\
(32.0558)\end{array}$ & & $\begin{array}{c}10.8^{* *} \\
(3.7362)\end{array}$ & $\begin{array}{c}10.0872^{*} \\
(3.697)\end{array}$ & \\
\hline Observations & 55 & 55 & 55 & 20 & 20 & 20 \\
\hline$R^{2}$ & 0.13 & 0.23 & 0.82 & 0 & 0.1 & 0.99 \\
\hline
\end{tabular}

${ }^{*} p<0.05,{ }^{* *} p<0.01,{ }^{* * *} p<0.001$ 


\section{House of Lords Topics}

Table D.3 shows the words with highest probabilities for the topics whose proportion was larger than 0.05 for each of the selected years in the House of Lords. The presented estimates are derived from the LDA model with 10 topics.

Table D.3: Top Words by Topic and Period in the House of Lords

\begin{tabular}{|c|c|c|}
\hline Topic & Proportion & Words \\
\hline \multicolumn{3}{|r|}{1625 (Useless Parliament) } \\
\hline Latin I & 0.704 & ds comes epus de lord vicecomes et lords house unto \\
\hline Latin II & 0.127 & et ad qui suum constituit ac domini procuratorem angliæ nostro \\
\hline Crown/Fiscal & 0.108 & majesty king shall pounds upon thousand answer religion may majesty's \\
\hline \multicolumn{3}{|r|}{1642 (Civil War) } \\
\hline Procedural & 0.417 & house commons shall lord answer ordered message parliament lords lordships \\
\hline Fiscal & 0.154 & shall parliament commons order lords persons city money county enter \\
\hline Crown & 0.112 & majesty kingdom parliament us great majesty's may many good petition \\
\hline Legislative & 0.076 & shall county parliament every houses commission peace persons instructions warrant \\
\hline Judicial & 0.055 & bill bishops time attorney lordships diem keeper videlicet ireland aforesaid \\
\hline \multicolumn{3}{|r|}{1662 (Restoration) } \\
\hline Legislative I & 0.803 & ds comes epus bill de house ordered act committee bp \\
\hline Legislative II & 0.097 & commons conference house act lord shall lordships agree concerning words \\
\hline \multicolumn{3}{|r|}{1689 (Glorious Revolution) } \\
\hline Legislative I & 0.598 & comes ds epus house bill de lords dux vicecomes act \\
\hline Legislative II & 0.156 & ordered petition cause day john versus house spiritual ten may \\
\hline Crown & 0.065 & majesty may commons address king message oaths majesty's lords great \\
\hline
\end{tabular}




\section{E Legislative Acts Topics}

Table E. 4 shows the words with highest probabilities for the topics whose proportion was larger than 0.05 for each of the selected years in the legislative acts. The presented estimates are derived from the LDA model with 10 topics.

Table E.4: Top Words by Topic and Period in Legislative Acts

\begin{tabular}{|c|c|c|}
\hline Topic & Proportion & Words \\
\hline \multicolumn{3}{|r|}{1625 (Useless Parliament) } \\
\hline $\begin{array}{l}\text { Miscellaneous } \\
\text { Parliament } \\
\text { Clergy } \\
\text { Alcohol }\end{array}$ & $\begin{array}{l}0.643 \\
0.104 \\
0.070 \\
0.068\end{array}$ & $\begin{array}{l}\text { er every co shall shalbe re son subsidies aforesaid sons } \\
\text { session end cornewall adjournement assent acts mannor sent determine statutes } \\
\text { three ro payment highnes due incumbent clergie province graunt acquittance } \\
\text { victualling house jac alehouse inne tipling houses markett hamlett victualler }\end{array}$ \\
\hline \multicolumn{3}{|r|}{1642 (Civil War) } \\
\hline $\begin{array}{l}\text { Miscellaneous } \\
\text { Private } \\
\text { Maritime }\end{array}$ & $\begin{array}{l}0.603 \\
0.109 \\
0.084\end{array}$ & $\begin{array}{l}\text { shall parliament persons commons lords time upon aforesaid money ordinance } \\
\text { lord earl county lieutenant shall william john robert henry edward } \\
\text { ships rebels ireland taken sea high armes ammunition goods forth }\end{array}$ \\
\hline \multicolumn{3}{|r|}{1662 (Restoration) } \\
\hline $\begin{array}{l}\text { Miscellaneous } \\
\text { Maritime } \\
\text { Trade }\end{array}$ & $\begin{array}{l}0.599 \\
0.085 \\
0.063\end{array}$ & $\begin{array}{l}\text { shall aforesaid persons act person theire every upon time may } \\
\text { goods customes port ship ships majesties vessel england officers leather } \\
\text { company trade admiralty silke pretended silk prizes parliament rents buttons }\end{array}$ \\
\hline \multicolumn{3}{|r|}{1689 (Glorious Revolution) } \\
\hline $\begin{array}{l}\text { Miscellaneous } \\
\text { Taxes } \\
\text { Towns } \\
\text { Crime }\end{array}$ & $\begin{array}{l}0.667 \\
0.078 \\
0.066 \\
0.059\end{array}$ & $\begin{array}{l}\text { shall act persons aforesaid majestyes made person upon enacted every } \\
\text { commissioners every pay within summe person } £ \text { pounds charged two } \\
\text { mayor city judgment citizens since judgement companies grants election liberties } \\
\text { excepted pardon alsoe offences committed since pardoned issues march fines }\end{array}$ \\
\hline
\end{tabular}




\section{F Lagged Models of Power}

We also check for the possibility that we observe an inverse relationship between agenda-setting and increase in parliamentary power. In other words, that we are merely observing a self-reinforcing mechanism between the two, we fit a linear model with our estimates of parliamentary power as an outcome variable and lagged number of parliamentary acts adopted (from the preceeding year) as one of the explanatory variables. As table F.5 illustrates, while our measure is significantly associated with the length of parliamentary sessions, it does not appear to be a simple reflection of the prior gains in power and consitutes a distinct agenda-setting strategy.

Table F.5: Lagged models of power

\begin{tabular}{cccc}
\hline & \multicolumn{3}{c}{ Parliamentary Power $(1604-1699)$} \\
\cline { 2 - 4 } & $(1)$ & $(2)$ & $(3)$ \\
\hline Acts $($ lag $=1)$ & 0.0023 & $8 \mathrm{e}-04$ & $6 \mathrm{e}-04$ \\
& $(0.0014)$ & $(0.0011)$ & $(0.001)$ \\
Days in sessions & & $0.0019^{* * *}$ & $0.0017^{* * *}$ \\
Crown FE & & $(3 \mathrm{e}-04)$ & $(3 \mathrm{e}-04)$ \\
Constant & $1.1774^{* * *}$ & $0.8666^{* * *}$ & $\checkmark$ \\
\hline Observations & $(0.0778)$ & $(0.0753)$ & \\
$R^{2}$ & 54 & 54 & 54 \\
\hline$* p<0.05,{ }^{* *} p<0.01,{ }^{* * *} p<0.001$ & 0.98 \\
\hline
\end{tabular}




\section{G Additional Results}

\section{G.1 Parliamentary Power Trends (16-17 cc.)}

While the central part of our analysis is restricted to the seventeenth century for both substantive and data-availability reasons, as figure 1 in the main text shows, Journals for the House of Commons and the House of Lords are available for parts of the preceeding sixteenth century. As there is a considerable debate about the strengthening of the Parliament in late Tudor period prior to the rule of Elizabeth I (1558-1603) (Elton 1953; Hurstfield 1973; Stasavage 2020), our measure of institutional power can provide some empirical evaluation of this argument. Figure G.5 shows the estimates of mean yearly topic entropy for late sixteenth and seventeenth centuries. High estimates for the House of Commons during short reigns of Edward VI and Mary I and a downward trend in parliamentary power with the beginning of the Elizabethan era lend support to the position that the Parliament played an important role in late Tudor years before Elizabeth I came to power.
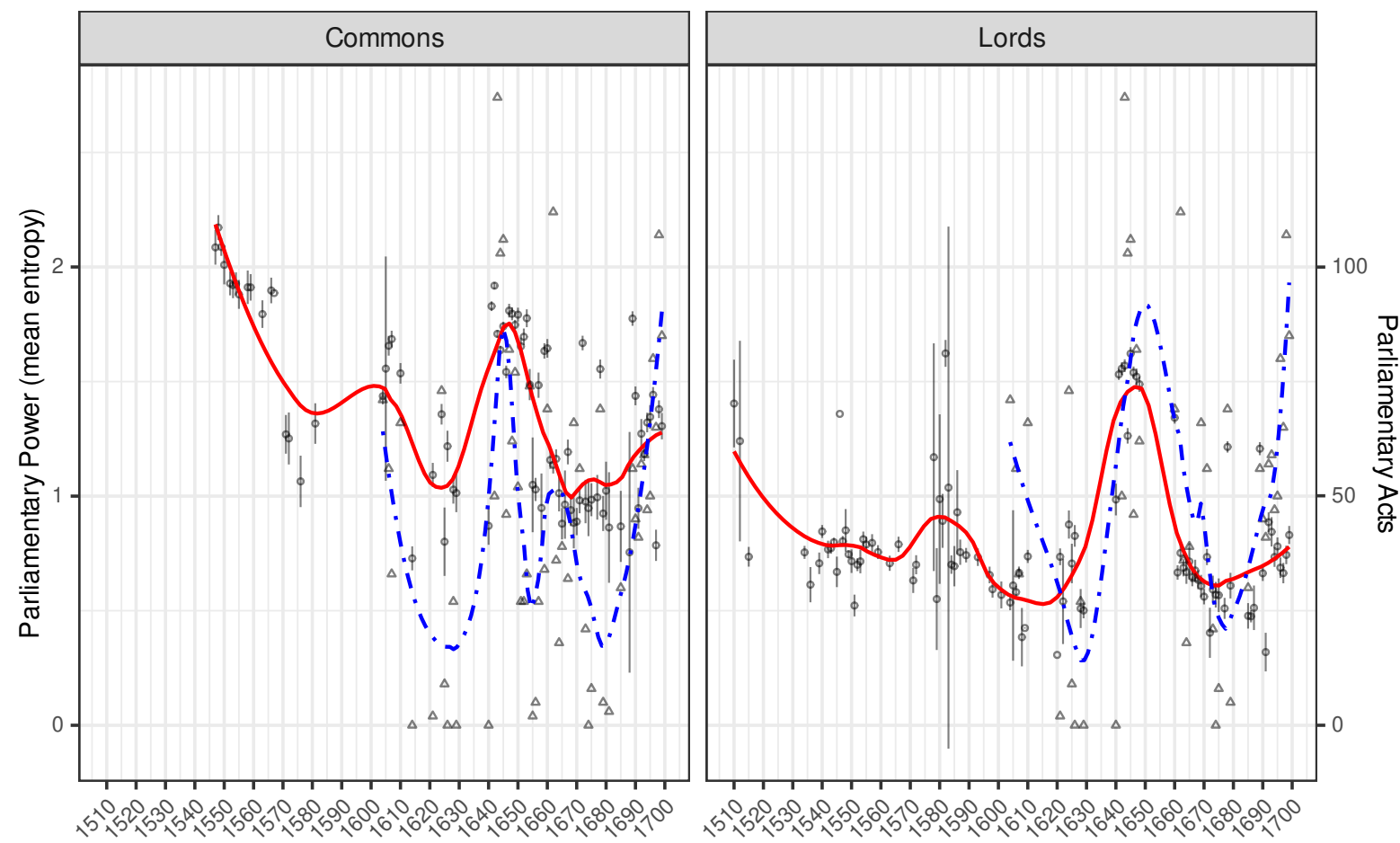

Figure G.5: Trends in Parliamentary Power Across both Houses During the Late Sixteenth and Seventeenth Centuries 


\section{G.2 Petitions}

As we mention in the manuscript, a potential explanation of changes in MP's agenda-setting strategy has to do with compositional changes in either the House of Commons or the House of Lords. Thus, if different profiles-with different characteristics and hence different preferences-become MP, this might have caused a change in the type of topics discussed in the Parliament.

A second potential interpretation of the findings is that citizens push MPs to discuss a wider set of issues. In other words, in their efforts to set the agenda, MPs might have been cued by the demand-side of the process, that is, citizens' preferences. In order to check this possibility, we scraped several collections of petitions stored at the British History Online. This includes the 'Petitions in the State Papers', a sample of 387 petitions submitted to the monarch and other authorities between 1600 and 1699, as well as other petitions to different judicial chambers.

Using the new dataset on petitions, we then apply the same approach as described in the manuscript. This allows us to explore changes in entropy levels over time and compare them to the fluctuations in entropy levels in the House of Commons and House of Lords. Results are shown in Figure G.6 below. As it can be seen, entropy levels are essentially constant over the period of analysis. This implies that the agenda-setting strategy exercised by elites in the Commons responded to a larger extent to their own strategic calculations. Another and similar interpretation could be that most petitions during that period concerned judicial affairs, which constituted an important attribute in the relationship between the Parliament and the commons (Boucoyannis 2021).

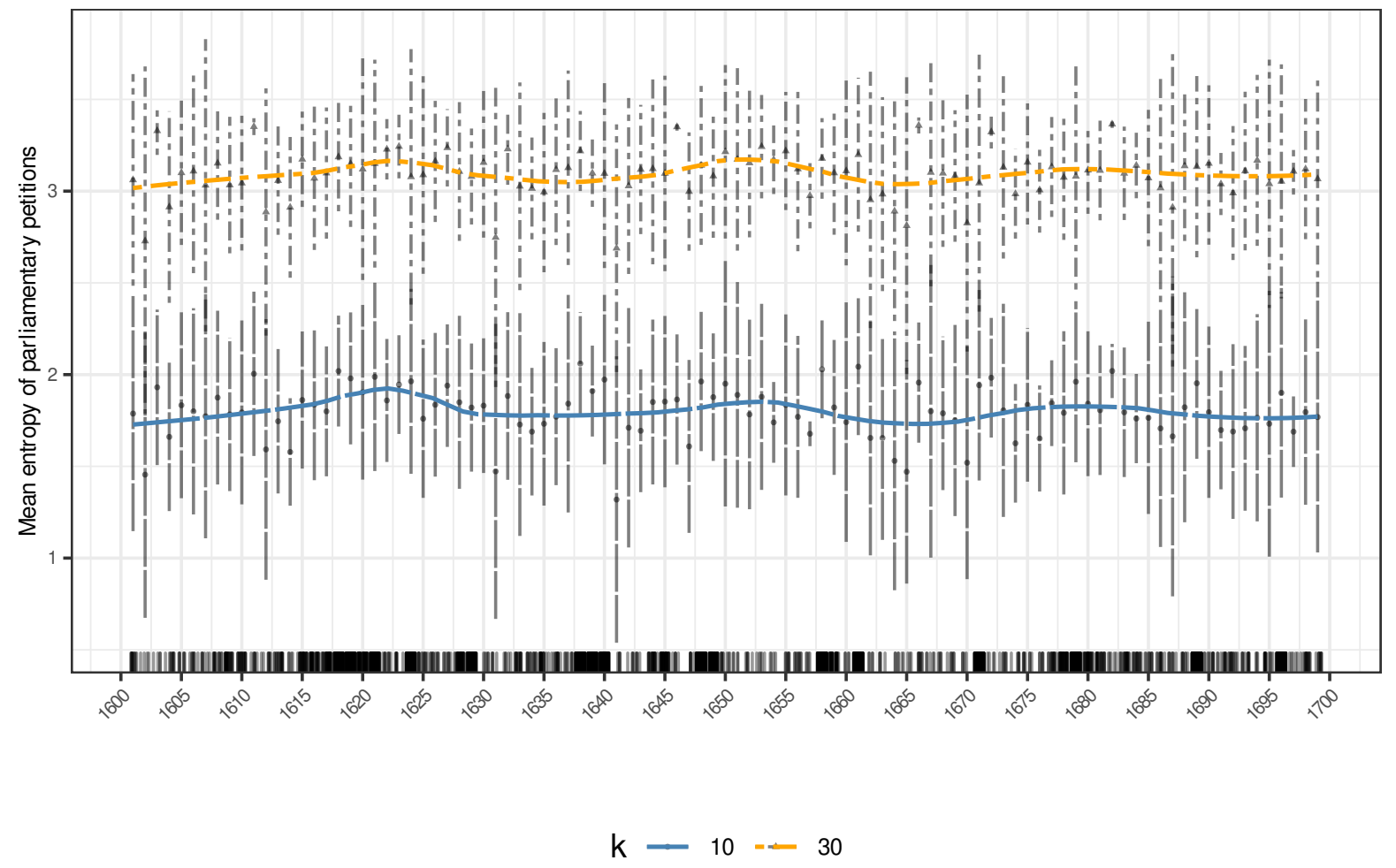

Figure G.6: Trend in Mean Entropy of Parliamentary Petitions During the Seventeenth Century. Marks along the $\mathrm{x}$-axis indicate concentrantion of petitions over time. 


\section{G.3 Mentions of Magna Carta}

One of the arguments made by parliamentarians in a attempt to expand their prerogatives during this period involved Magna Carta, a thirteenth-century royal charter granted by King John to rebel barons, confirming their rights and privileges. While the actual contemporaneous political significance of this document is still widely debated by scholars, it had undoubtedly become a powerful symbol and an important reference point for proponents of consensual government for centuries to come (Hill 1980; Stasavage 2020). One expectation that we might, thus, have is an increase in the number of references to Magna Carta over the seventeenth century, as the MPs were using it a yet another tool in an attempt to signal their sovereignty over the realm. Figure G.7 shows the yearly number of mentions of Magna Carta (or, more accurately, Magna Charta in accordance with Latin spelling used in the Journals), normalized by the number of documents in a given year. It appears to be most prominently in the last parliaments before the Civil War and around the time of the Glorious Revolution. The most likely explanation for this pattern could be an increased saliency of this document at times when parliament was involved in active bargaining with the Crown.

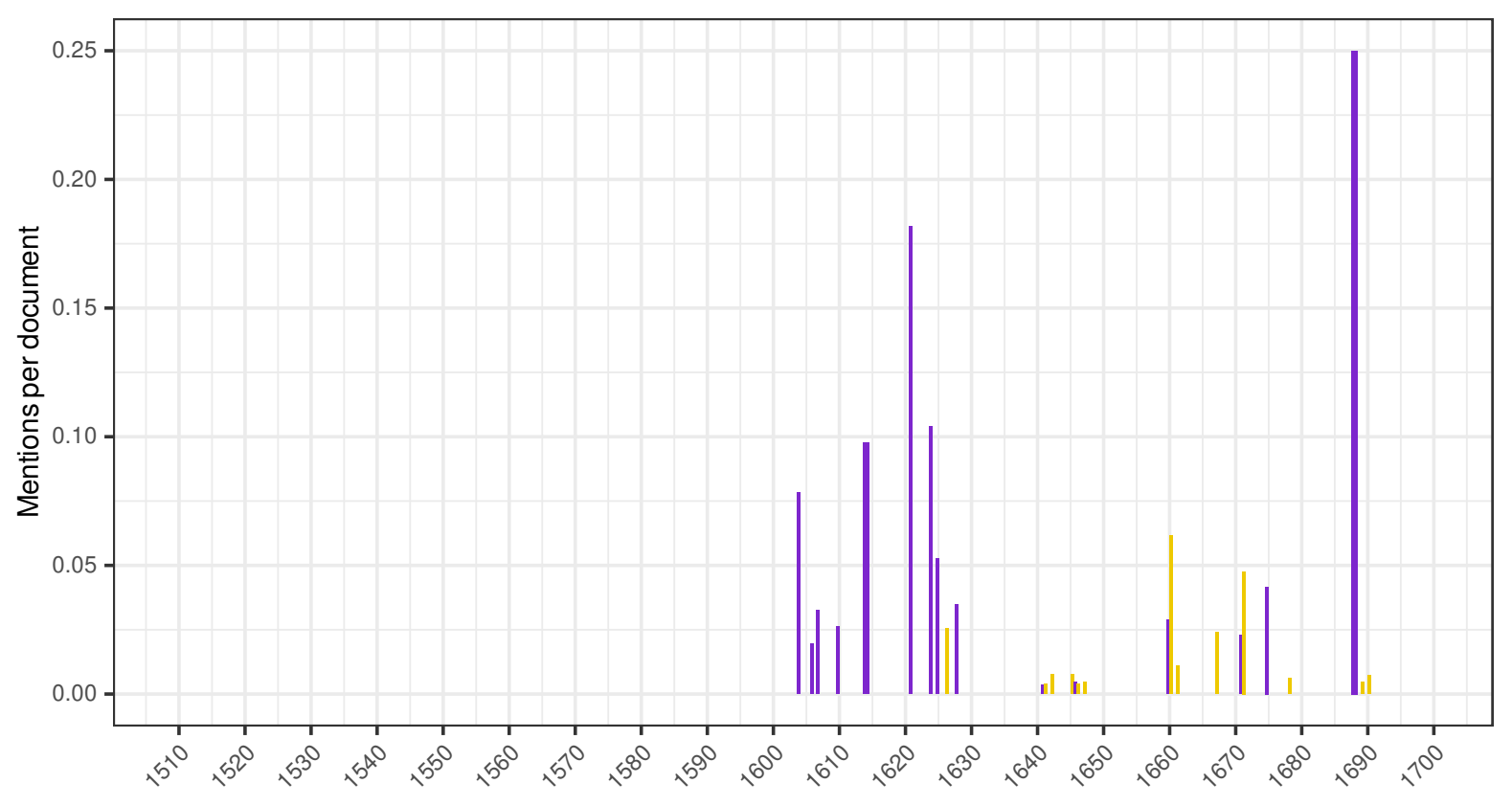

Commons

Lords

Figure G.7: Mentions of 'Magna Carta' in the Parliamentary Journals 


\section{G.4 Identifying Power Voids}

Apart from using the topic entropy-based measure for exploring the changes in institutional power and policy areas over time, it is helpful to relate it directly to the theory of power voids underpinning it. Power voids could be understood as structural breaks in the attention distribution over policy areas. In other words, sudden and abrupt expansions or shrinkages of institutional power can be viewed as successfully or unsuccessfully (from the perspective of the Parliament) exploited power voids. To check for changes in the institutional power it is possible to compare the means before/after the hypothesized breaks. As historical periodization of the seventeenth century Parliament is fairly well-understood (see section above), we apply structural breaks model proposed by Bai and Perron (2003) to identify them in a data-driven way and compare to those from historical literature.

We apply structural change model as implemented in strucchange (Zeileis et al. 2002) with standard defaults. Figures G.8 and G.9 show diagnostics using Bayesian information criterion (BIC) and residual sum of squares (RSS) for separate models for each of the chambers.

\section{BIC and Residual Sum of Squares}

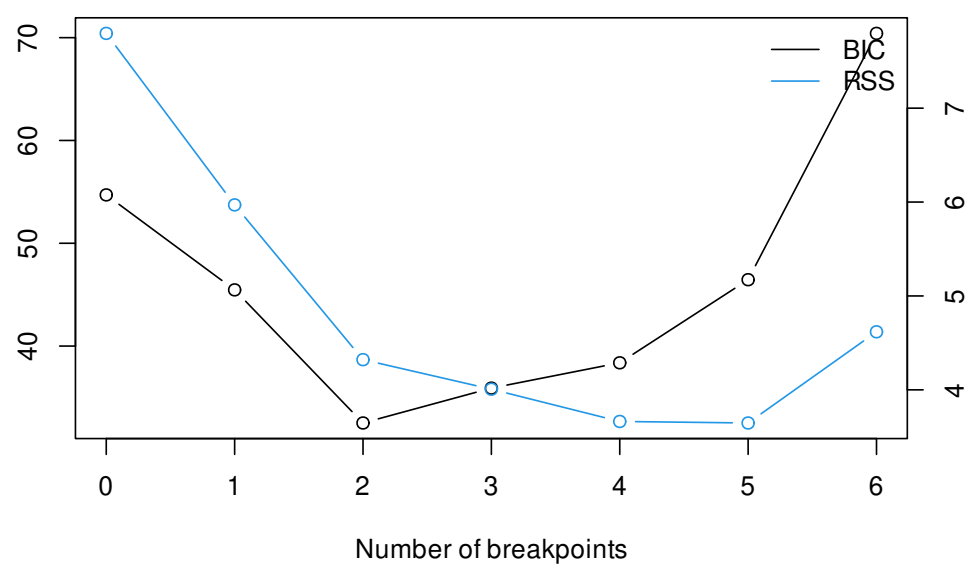

Figure G.8: House of Commons Diagnostics

BIC and Residual Sum of Squares

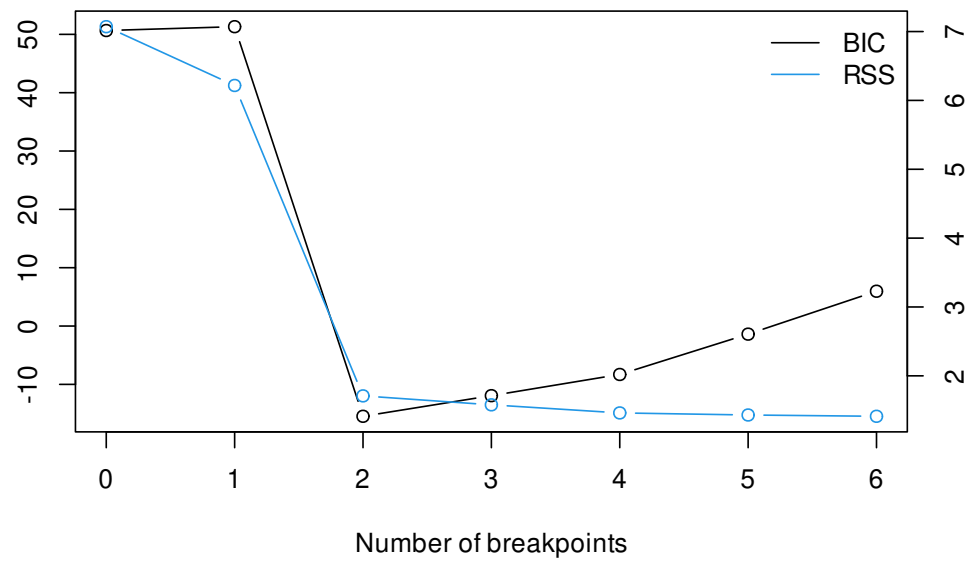

Figure G.9: House of Lords Diagnostics

Table G.6 reports the results for the House of Commons and the House of Lords. Using Bayesian information criterion for model selection, the optimal number of breaks is two for each chamber. However, the years 
Table G.6: Structural Breaks Test on Yearly Topic Entropies

\begin{tabular}{cccccccccc}
\hline & & \multicolumn{7}{c}{ Number of breaks } \\
\cline { 2 - 9 } & & 0 & 1 & 2 & 3 & 4 & 5 & 6 & Optimal breaks \\
\hline Commons & BIC & 54.70452 & 45.46515 & 32.51678 & 35.90696 & 38.370110 & 46.455308 & 70.416727 & 1640,1654 \\
Lords & BIC & 50.65741 & 51.31535 & -15.47024 & -11.93438 & -8.301526 & -1.387512 & 5.967858 & 1640,1660 \\
\hline
\end{tabular}

when these breaks occurred differ. The first power void successfully exploited by the Parliament happened in 1640, the year preceding the English Civil War. Considering the means of parliamentary power of the House of Commons for these periods: for 1604 to 1639 it is 1.26 , for 1641 to 1653 it increases to $1.74(p<0.001)$. For the second half of the century, including the Cromwell's Protectorate, the Restoration Parliament and the decade after the Glorious Revolution it drops to $1.47(p<0.001)$, the level lower than for the previous period, but higher than for the Early Stuart parliaments. The second break point, in 1654, could also be seen as a power void that the Parliament was not able to exploit, but which was successfully used, first, by Oliver Cromwell and later by Charles II.

A similar picture emerges for the House of Lords. The main difference here is that the second break point occurs in 1660. The reason for that is the abolition of the upper chamber from 1649 until 1660. The mean parliamentary power rises from 0.6 to 1.5 between 1604-1639 and 1641-1649 $(p<0.001)$ and then goes down to 0.9 for $1661-1699(p<0.001)$.

If we also consider the second-best model with three breaks, we can further separate the second part of the century into pre-Glorious Revolution (1655-1687) and post-Glorious Revolution (1689-1699) with 1688 as additional break point. Here the mean parliamentary power increases from 1.08 to $1.28(p<0.01)$.

Although the results of the break points analysis are broadly consistent with the common periodization of the seventeenth-century parliamentary history, the ability to automatically identify power voids in a systematic way, shows how upward and downward shifts reflected successful and less so attempts by the Parliament to expand its sovereignty over the realm. 


\section{H Software Statement}

The analysis was run under Linux Ubuntu 20.04 using $\mathrm{R}$ version 4.2.0 ( $\mathrm{R}$ Core Team 2022). We relied on the following $\mathrm{R}$ packages in our empirical analysis:

dplyr (Wickham et al. 2018),

ggplot2 (Wickham 2016),

kableExtra (Zhu 2018),

knitr (Xie 2018),

lubridate (Grolemund and Wickham 2011),

magrittr (Bache and Wickham 2014),

readr (Wickham, Hester, and Francois 2017),

stringi (Gagolewski 2018),

stringr (Wickham 2018),

strucchange (Zeileis et al. 2002),

tibble (Müller and Wickham 2018),

tidyr (Wickham and Henry 2018),

topicmodels (Grün and Hornik 2011), and

quanteda (Benoit et al. 2018). 


\section{References}

Bache, Stefan Milton, and Hadley Wickham. 2014. magrittr: A Forward-Pipe Operator for R. https: //CRAN.R-project.org/package=magrittr.

Bai, Jushan, and Pierre Perron. 2003. "Computation and Analysis of Multiple Structural Change Models." Journal of Applied Econometrics 18 (1): 1-22. https://doi.org/10.1002/jae.659.

Benoit, Kenneth, Kohei Watanabe, Haiyan Wang, Paul Nulty, Adam Obeng, Stefan Müller, and Akitaka Matsuo. 2018. "quanteda: An R package for the quantitative analysis of textual data." Journal of Open Source Software 3 (30): 774. https://doi.org/10.21105/joss.00774.

Blei, David M, Andrew Y Ng, and Michael I Jordan. 2003. "Latent Dirichlet Allocation." Journal of Machine Learning Research 3: 993-1022. https://doi.org/10.1162/jmlr.2003.3.4-5.993.

Boucoyannis, Deborah. 2021. Kings as Judges: Power, Justice, and the Origins of Parliaments. Cambridge: Cambridge University Press. https://doi.org/10.1017/9781316678367.

Chang, Jonathan, Sean Gerrish, Chong Wang, and David M Blei. 2009. "Reading Tea Leaves: How Humans Interpret Topic Models." In Advances in Neural Information Processing Systems 22, 288_296. https://doi.org/10.1.1.100.1089.

Deerwester, Scott, Susan T Dumais, George W Furnas, Thomas K Landauer, and Richard Harshman. 1990. "Indexing by Latent Semantic Analysis." Journal of the American Society for Information Science 41 (6): 391-407.

Elton, G. R. 1953. Tudor Revolution in Government. Cambridge University Press. https://doi.org/10.1017/ CBO9780511561115.

Gagolewski, Marek. 2018. R package stringi: Character string processing facilities. http://www.gagolewski.c om/software/stringi/.

Griffiths, Thomas L., and Mark Steyvers. 2004. "Finding Scientific Topics." Proceedings of the National Academy of Sciences 101 (suppl 1): 5228-35. https://doi.org/10.1073/pnas.0307752101.

Grolemund, Garrett, and Hadley Wickham. 2011. "Dates and Times Made Easy with lubridate." Journal of Statistical Software 40 (3): 1-25. http://www.jstatsoft.org/v40/i03/.

Grün, Bettina, and Kurt Hornik. 2011. "topicmodels: An R Package for Fitting Topic Models." Journal of Statistical Software 40 (13): 1-30. https://doi.org/10.18637/jss.v040.i13.

Henning, Basil Duke, ed. 1983. The History of Parliament. The House of Commons, 1660-1690, Vol. I. London: Secker \& Warburg, for the History of Parliament Trust.

Hill, Christopher. 1980. The Century of Revolution, 1603-1714. New York: Norton.

Hirst, Derek. 1975. The Representative of the People? Voters and Voting in England under the Early Stuarts. Cambridge: Cambridge University Press. https://doi.org/10.1017/CBO9780511561177.

Hofmann, Thomas. 1999. "Probabilistic Latent Semantic Analysis." In Uncertainity in Artifitial Intelligence - UAI'99, 289-96. https://doi.org/10.1.1.33.1187.

Hurstfield, Joel. 1973. Freedom, corruption, and government in Elizabethan England. Cambridge: Harvard University Press.

Müller, Kirill, and Hadley Wickham. 2018. tibble: Simple Data Frames. https://CRAN.R-project.org/pack age $=$ tibble.

Phan, Xuan-Hieu, Le-Minh Nguyen, and Susumu Horiguchi. 2008. "Learning to Classify Short and Sparse Text \& Web with Hidden Topics from Large-Scale Data Collections." In Proceedings of the 17th International Conference on World Wide Web, 91-100. https://doi.org/10.1145/1367497.1367510.

R Core Team. 2022. R: A Language and Environment for Statistical Computing. Vienna, Austria: R Foundation for Statistical Computing. https://www.R-project.org/.

Stasavage, David. 2020. The Decline and Rise of Democracy: A Global History from Antiquity to Today. Princeton: Princeton University Press.

Wickham, Hadley. 2016. ggplot2: Elegant Graphics for Data Analysis. Springer-Verlag New York. http: //ggplot2.org.

- 2018. stringr: Simple, Consistent Wrappers for Common String Operations. https://CRAN.Rproject.org/package=stringr.

Wickham, Hadley, Romain François, Lionel Henry, and Kirill Müller. 2018. dplyr: A Grammar of Data Manipulation. https://CRAN.R-project.org/package=dplyr.

Wickham, Hadley, and Lionel Henry. 2018. tidyr: Easily Tidy Data with 'spread()' and 'gather()' Functions. https://CRAN.R-project.org/package=tidyr. 
Wickham, Hadley, Jim Hester, and Romain Francois. 2017. readr: Read Rectangular Text Data. https: //CRAN.R-project.org/package $=$ readr.

Xie, Yihui. 2018. knitr: A General-Purpose Package for Dynamic Report Generation in R. https://yihui.na me/knitr/.

Zeileis, Achim, Friedrich Leisch, Kurt Hornik, and Christian Kleiber. 2002. "strucchange: An R Package for Testing for Structural Change in Linear Regression Models." Journal of Statistical Software 7 (2): 1-38. http://www.jstatsoft.org/v07/i02/.

Zhu, Hao. 2018. kableExtra: Construct Complex Table with 'kable' and Pipe Syntax. https://CRAN.Rproject.org $/$ package $=$ kableExtra. 